\title{
An update on the techniques used to measure oxidative stress in seminal plasma
}

\author{
Kathy A. Robert ${ }^{1}$ (D) | Rakesh Sharma ${ }^{1}$ (D) | Ralf Henkel $^{2}$ (D) | Ashok Agarwal ${ }^{1}$ (C)
}

\author{
${ }^{1}$ American Center for Reproductive \\ Medicine, Cleveland Clinic, Cleveland, $\mathrm{OH}$ \\ USA \\ ${ }^{2}$ Department of Medical Bioscience, \\ University of the Western Cape, Bellville, \\ South Africa

\section{Correspondence} \\ Ashok Agarwal, American Center for \\ Reproductive Medicine, Cleveland Clinic, \\ Cleveland, Ohio, USA. \\ Email: agarwaa@ccf.org
}

\begin{abstract}
Reactive oxygen species (ROS) are produced in significant amounts by spermatozoa and leucocytes. They are necessary to carry out various physiological functions such as sperm capacitation, hyperactivation, acrosome reaction, sperm-zona binding and cellular signalling pathways. Oxidative stress (OS) results when the ROS levels overwhelm the available antioxidant reserve. A number of direct and indirect tests have been developed to assess oxidative stress. In this manuscript, we discuss these common direct and indirect tests as well as their advantages and disadvantages. Tests measuring sperm dysfunction secondary to oxidative stress such as lipid peroxidation, DNA fragmentation and protein alterations are also described.
\end{abstract}

\section{KEYWORDS}

DNA integrity, lipid peroxidation, oxidation-reduction potential, reactive oxygen species, spermatozoa

\section{1 | BACKGROUND}

\section{1 | Male infertility}

Globally, about $15 \%$ of couples desiring pregnancy are infertile and male factor is responsible for about $30 \%$ to $50 \%$ of these cases (Agarwal, et al., 2019; Sigman, Lipshultz, \& Howards, 2009). Environmental, physiological and genetic factors affect sperm function leading to infertility (Durairajanayagam, 2018). Semen analysis is the first step in the laboratory evaluation of male infertility. A semen analysis by itself is only a diagnostic test, it cannot determine the cause of infertility. In about $20 \%$ of the cases termed as idiopathic infertility, the cause is unknown (Agarwal, et al., 2019; Cooper et al., 2010; World Health Organization, 2010). This diagnostic limitation of semen analysis introduced the need to identify markers to understand the underlying molecular mechanism responsible for infertility. One such marker is oxidative stress (OS). Oxidative stress is a major player in the pathology of male infertility (Agarwal et al., 2006; Agarwal, Virk, Ong, \& du Plessis, 2014).

OS is involved in the majority of known clinical, environmental and lifestyle causes of male infertility (Agarwal \& Sengupta, 2020; Durairajanayagam, 2018). Furthermore, OS is implicated in the pathophysiology of infertility due to varicocele, genitourinary tract infection, prostatitis, obesity, tobacco smoking, endocrine imbalance and testicular dysfunction (Darbandi et al., 2018; Tremellen, 2008; Wagner, Cheng, \& Ko, 2018; Wright, Milne, \& Leeson, 2014). The plasma membrane of the spermatozoa is rich in polyunsaturated fatty acids (PUFAs) and therefore very susceptible to oxidation causing sperm dysfunction. This results in infertility, fertilisation failure, pregnancy loss, poor embryonic development and even childhood cancer (Fujii \& Imai, 2014; Wahab, Yazmie, Isa, \& Lokman, 2015). In this review, we will highlight the significance of OS in male infertility and describe the assays currently available for its evaluation.

\subsection{Mechanism of oxidative stress as a cause of infertility}

Much like every other biological cell, oxygen is required by the mitochondria for energy producing processes via the oxidative phosphorylation pathway. This involves the oxidation and reduction of molecules consequently producing highly reactive molecules known as free radicals (Bisht \& Dada, 2017; Bisht, Faiq, Tolahunase, 
\& Dada, 2017; Sharma \& Agarwal, 2020). Reactive oxygen species (ROS) are highly reactive and very unstable molecules which possess one or more unpaired electrons (Nakajima et al., 2002; Nohl et al., 2000; Vezin et al., 2002). Superoxide anion $\left(\mathrm{O}_{2}^{-\bullet}\right)$, hydroxylradical $(\mathrm{OH} \bullet)$, hydrogen peroxide $\left(\mathrm{H}_{2} \mathrm{O}_{2}\right)$, hypochlorous acid $(\mathrm{HOCl})$ and reactive nitrogen species such as peroxynitrite $\left(\mathrm{ONOO}^{-}\right)$and nitric oxide $(\bullet N O)$ are all examples of ROS. ROS can be produced endogenously by seminal polymorphonuclear leucocytes (Aitken \& Baker, 2013; Henkel, 2011; Mupfiga, Fisher, Kruger, \& Henkel, 2013) and morphologically abnormal spermatozoa. Spermatozoa with excessive residual cytoplasm as a result of incomplete sperm maturation also have the ability to produce ROS (Aitken, 2017; Gomez et al., 1996). Furthermore, abnormalities in the mitochondria occur due to leakage of electrons from cytosolic L-amino acid oxidases and plasma membrane nicotinamide adenine dinucleotide phosphate (NADP) oxidases (Aitken, 2017; Ford, 2004; Koppers, De Iuliis, Finnie, McLaughlin, \& Aitken, 2008). Exogenous sources include tobacco smoking, alcohol usage, radiation, pollution, testicular heat and other environmental toxicants (Tremellen, 2008; Wright et al., 2014; Figure 1).

Redox balance is essential for normal sperm function (Aitken, 2017; Aitken \& Curry, 2011; Du Plessis, Agarwal, Halabi, \& Tvrda, 2015; de Lamirande, Jiang, Zini, Kodama, \& Gagnon, 1997; Wagner et al., 2018). OS is a result of high levels of ROS or a depleted antioxidant capacity in sperm cells (Bisht \& Dada, 2017). Spermatozoa are exposed to OS during spermatogenesis, epididymal storage and transit through the reproductive tract and at the time of ejaculation (Aitken \& Curry, 2011; Sakkas \& Alvarez, 2010 Tremellen, 2008). Limited availability of intracellular antioxidants and elevated ROS levels expose the vulnerable molecules to oxidative attack (Aitken, 2017; Aitken \& Curry, 2011).

\section{2 | ROLE OF ROS IN SEMINAL PLASMA}

\section{1 | Physiological role}

Controlled amounts of ROS are essential for the spermatozoa to acquire fertilising capacity. Physiological levels of ROS regulate the intracellular calcium concentration as well as the enzymatic tyrosine kinase activity required for capacitation and hyperactivation; a physiological condition where the sperm motility is dramatically enhanced. Only capacitated spermatozoa display hyperactivated motility and undergo the acrosome reaction necessary for fertilisation. Incubation of spermatozoa with exogenous oxidants such as $\mathrm{O}_{2}^{-\bullet}, \mathrm{H}_{2} \mathrm{O}_{2}$ and $\bullet \mathrm{NO}$ results in capacitation, hyperactivation and acrosome reaction and helps in oocyte fusion (Aitken, 2017; Aitken \& Curry, 2011; Dutta, Henkel, Sengupta, \& Agarwal, 2020; Makker, Agarwal, \& Sharma, 2009; Tremellen, 2008). Physiological levels of ROS are also essential for chromatin and flagellar protein modifications during spermatogenesis (O'Flaherty \& Matsushita-Fournier, 2017).

\subsection{Pathological role}

Although ROS is involved in the regulation of physiological processes of the spermatozoa, an excess of ROS can impair cellular constituents affecting cell signalling and sperm function. The PUFAs render the spermatozoa more susceptible to lipid peroxidation, which results in the formation of potentially toxic and mutagenic aldehydes and alkanols causing DNA fragmentation (Figure 1) (Aitken, 2017; Aitken, Gibb, Baker, Drevet, \& Gharagozloo, 2016; Henkel, 2011; Moazamian et al., 2015; Sharma \& Agarwal, 2020).

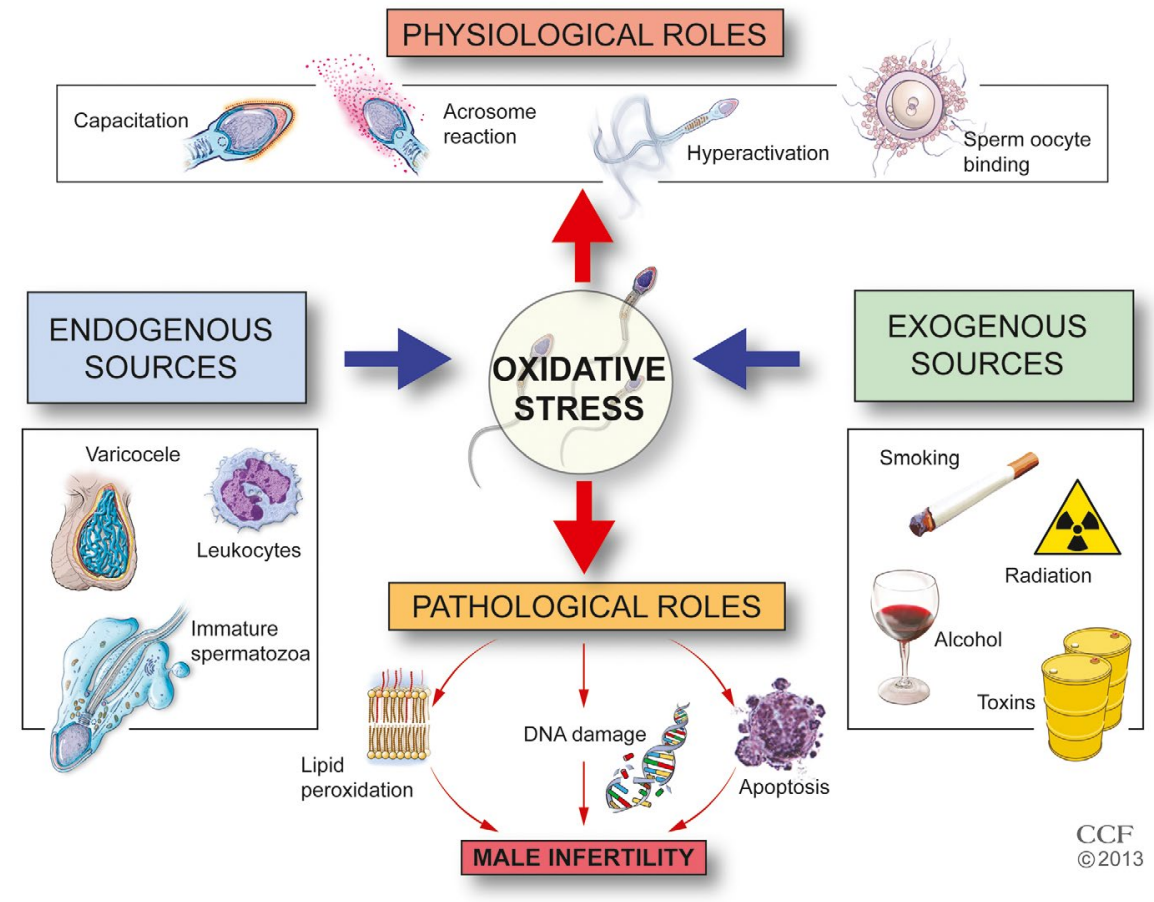

FIGURE 1 Physiological and pathological role of reactive oxygen species (ROS) and generation of excessive ROS by endogenous and exogenous sources of seminal reactive oxygen species 
OS results in increased DNA damage, reduced motility, impaired acrosome reaction and decreased implantation rates in vitro fertilisation (IVF) (Aitken, 2017; Aitken \& Curry, 2011; Bakos, Henshaw, Mitchell, \& Lane, 2011; Palmer, Bakos, Fullston, \& Lane, 2012; Tremellen, 2008; Wahab, Isa, \& Ramli, 2016). It also interferes with epigenetic modifications and may result in abnormallities in sperm gene methylation (Darbandi et al., 2018; Menezo, Silvestris, Dale, \& Elder, 2016; Tunc \& Tremellen, 2009). Consequently, DNA damage may also result in impairment of embryo development, increased risk of gene mutations and miscarriage, congenital malformations and increased incidence of diseases in the offspring (Aitken \& Curry, 2011; Aitken et al., 2016; Aitken \& Koppers, 2011; Bisht \& Dada, 2017; Muratori et al., 2015; Sakkas \& Alvarez, 2010; Wright et al., 2014). The role of OS in male infertility is well established and has led to a number of direct and indirect laboratory tests to measure OS in the semen.

\section{3 | LABORATORY EVALUATION OF OXIDATIVE STRESS}

OS levels can be evaluated by various direct and indirect methods, which are listed in Table 1 and further described below.

\section{1 | Direct methods}

Direct tests measure the concentration of oxidant molecules and include chemiluminescence assay, nitro blue tetrazolium (NBT) assay, cytochrome $\mathrm{C}$ reduction test, electron spin resonance technique and oxidation-reduction potential (ORP).

\subsection{1 | ROS measurement by chemiluminescence assay}

Chemiluminescence assay is the most widely used direct test for quantification of ROS in semen (Agarwal, Ahmad, \& Sharma, 2015). The two commonly used probes for measurement of ROS are luminol (5-amino-2,3-dihydro-1,4-phthalazinedione) and lucigenin (10,10'-dimethyl-9,9'-biacridiniumdinitrate). Luminol is a yellow-coloured, membrane permeable cyclic diacylhydrazide used to detect both global intracellular and extracellular ROS. However, it cannot discriminate the different types of oxidants. Lucigenin is a membraneimpermeable probe used to measure the extracellular $\mathrm{O}_{2}^{-\bullet}$ (Agarwal, Ahmad, et al., 2015). When measuring global ROS with luminol, a working solution ( $5 \mathrm{mM}$ ) of luminol is prepared in dimethyl sulfoxide (DMSO) and a blank, negative and a positive control is used along with the test sample. (Figure 2). The analysis is conducted using a luminometer (Figure 3). The chemiluminescent signals are expressed in relative light units (RLU). The results for test samples are obtained by subtracting the average RLU of negative control from the test sample (Agarwal, Ahmad, et al., 2015). The samples are normalised for sperm concentration by dividing the ROS value by the sperm concentration and results are expressed as RLU/10 6 sperm $/ \mathrm{mL}$ of semen (Agarwal, Ahmad, et al., 2015). A cut-off of $<102.2 \mathrm{RLU} / \mathrm{s} / 10^{6} \mathrm{sperm} / \mathrm{mL}$ can discriminate fertile from infertile men (Agarwal, Ahmad, et al., 2015).

\subsection{2 | Nitroblue tetrazolium test}

Nitroblue tetrazolium test (NBT) assesses the intracellular ROS produced by spermatozoa and leucocytes. Nitroblue tetrazolium (2,2'-bis (4-nitrophenyl)-5,5'-diphenyl-3,3'-(3,3'-dimethoxy-4,4'-diphenylene) ditetrazolium chloride is a yellow-coloured water-soluble nitro-substituted aromatic tetrazolium compound. In the presence of cellular $\mathrm{O}_{2}^{-\bullet}$, it is converted to a water-insoluble formazan crystal (Baehner, Boxer, \& Davis, 1976; Gosalvez, Tvrda, \& Agarwal, 2017; Tunc, Thompson, \& Tremellen, 2010). In the sperm cytoplasm, NADPH is synthesised by glucose-6-phosphate dehydrogenase via the hexosemonophosphate pathway. NADPH contributes to the synthesis of superoxide anions by NADPH oxidase. The same enzyme catalyses the reduction of NBT into formazan. It also indirectly provides a measure for ROS generation in cytoplasm. The reduced formazan is easily detected microscopically (Esfandiari, Sharma, Saleh, Thomas, \& Agarwal, 2003) or spectrophotometrically (Gosalvez et al., 2017; Tunc et al., 2010). Alternately, it can also be detected using kit such as Oxisperm ${ }^{\circledR}$ kit (Halotech ${ }^{\circledR}$ DNA).

\subsection{3 | Cytochrome $\mathrm{C}$ reduction test}

The Cytochrome $\mathrm{C}$ reduction test is a colorimetric assay used to detect extracellular $\mathrm{O}_{2} \bullet-$ released by cells and causes the reduction
TABLE 1 Direct and indirect assays used to evaluate sperm DNA fragmentation

$\begin{array}{ll}\text { Test } & \text { Test principle } \\ \text { Direct } & \\ \text { Comet assay } & \text { Evaluates the integrity of DNA, double- and single-strand breaks } \\ \text { TUNEL assay } & \text { Evaluates DNA fragmentation, double- and single-strand breaks } \\ \text { Indirect } & \text { Evaluates the susceptibility of sperm DNA to acid denaturation } \\ \text { SCSA } & \text { Evaluates the susceptibility of sperm DNA to acid denaturation } \\ \text { SCD or Halo test } & \text { Evaluates double- and single-strand breaks } \\ \text { AOT } & \end{array}$

Abbreviation: AOT, acridine orange test; SCSA, sperm chromatin structure assay; SCD, sperm chromatin dispersion; TUNEL, terminal deoxynucleotidyl transferase dUTP nick end labelling. 


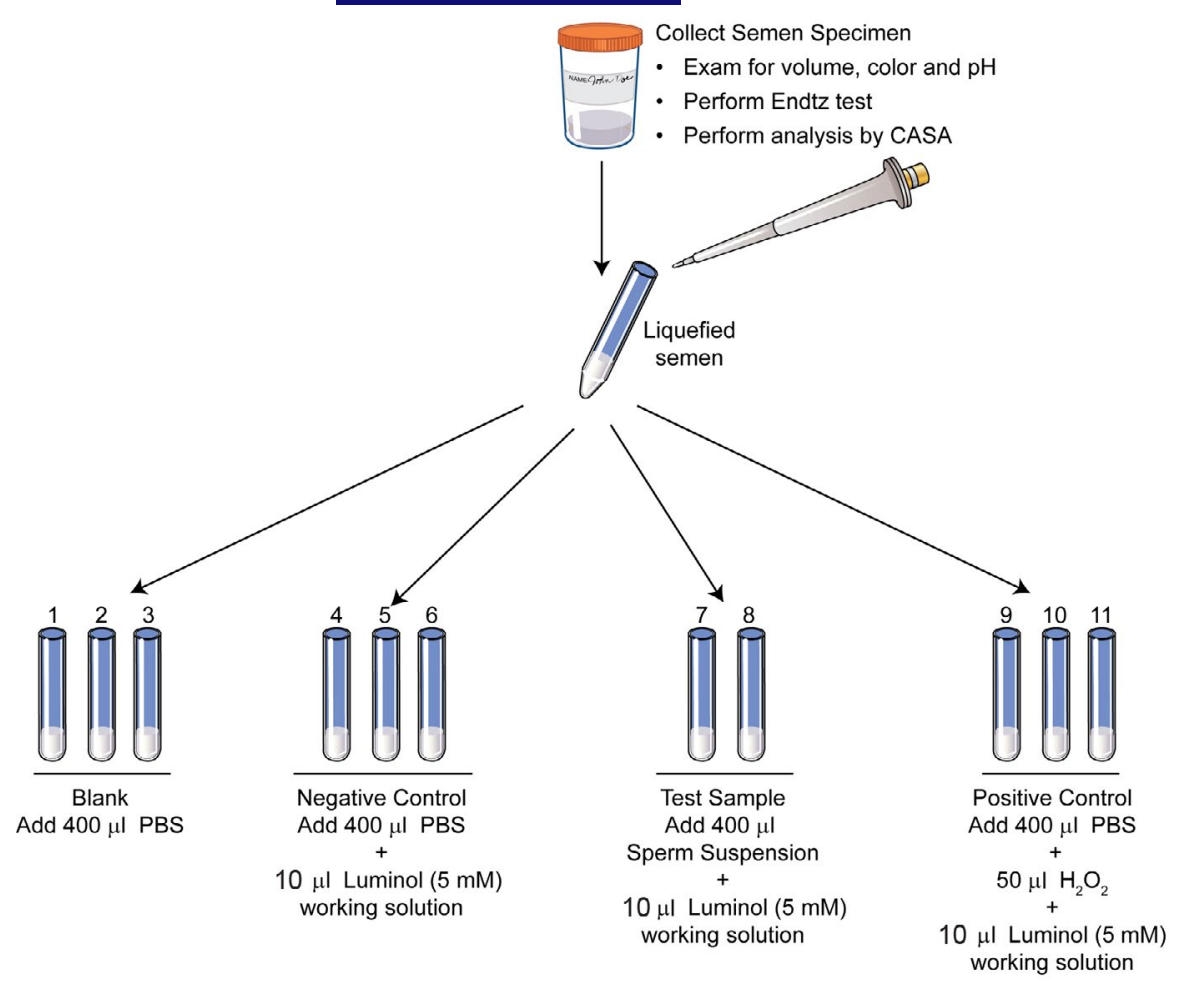

FIGURE 2 Set-up of the tubes for reactive oxygen species measurement. A total of 11 tubes are labelled from S1S11: Blank, negative control, test sample and positive control. Luminol is added to all tubes except the blank. Hydrogen peroxide is added only to the positive control

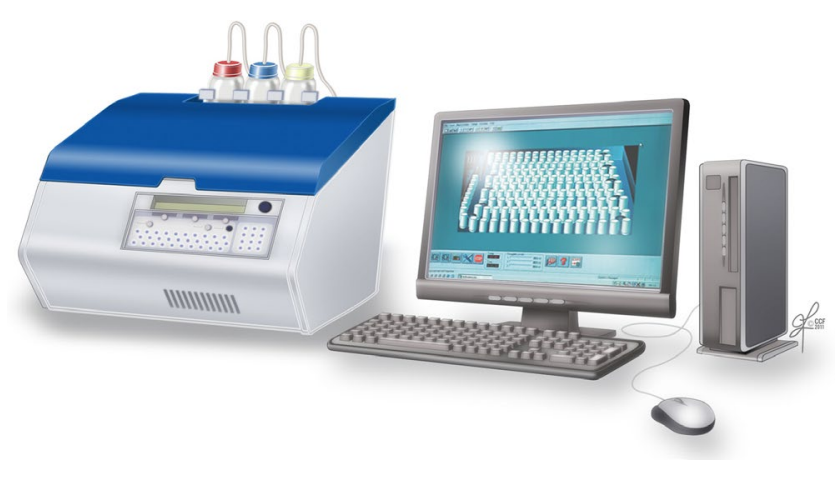

FIGURE 3 Autolumat 953 Plus Luminometer used in the measurement of reactive oxygen species (ROS) by chemiluminescence assay. Multiple tubes can be loaded simultaneously for measuring ROS. The luminometer can be connected with a computer and monitor

of ferricytochrome $\mathrm{C}$ to ferrocytochrome $\mathrm{C}$ by NADPH dependent cytochrome $C$ reductase. The reaction is analysed spectrophotometrically at 550nm absorbance (Dikalov \& Harrison, 2014). Various commercially available kits can be used with a cuvette or in a microplate. The spectrophotometer is set at $550 \mathrm{~nm}$ in the kinetic programme. A blank (NADH ${ }^{+}$Buffer) and a positive control $\left(\mathrm{NADPH}^{+}\right.$ Cytochrome $\mathrm{C}$ Reductase enzyme) are included in the assay. The test is performed by adding superoxide dismutase (SOD) to selectively measure $\mathrm{O}_{2} \bullet^{-}$mediated reduction (Dikalov \& Harrison, 2014). Dismutation of $\mathrm{O}_{2} \bullet^{-}$into $\left(\mathrm{H}_{2} \mathrm{O}_{2}\right)$ is catalysed by SOD, and the resulting SOD-inhibited signal is used to normalise the results. The results are expressed as NADPH-Cytochrome c Reductase (NCR) unit. One unit of NCR activity is the enzyme that generates 1 micromole of reduced cytochrome $\mathrm{C}$ per minute.

\subsection{4 | Electron spin resonance/electron paramagnetic resonance}

Electron spin resonance (ESR) spin-trapping uses the nitrone compound to detect oxygen free radicals such as $\mathrm{O}_{2} \bullet{ }^{-}$and $\mathrm{HO} \bullet$ utilising magnetic resonance spectroscopy (Kohno, 2010). Electrons are characterised by the angular momentum of the electron demonstrated as a spin quantum number. When an external magnetic field is applied, the electrons orient themselves either parallel or antiparallel to the magnetic field. This results in two distinct energy levels for the unpaired electrons. By using a fixed frequency of microwave irradiation, some of the electrons in the lower energy level are excited to the higher energy level leading to absorption of energy (Kopáni, Celec, Danišovič, Michalka, \& Biró, 2006).

ROS molecules can be detected by the using the 'spin-trap' strategy as well as by hydroxylamine spin probes because they have a very short half-life (Dikalov, Polienko, \& Kirilyuk, 2018; Kohno, 2010). The spin-trap approach is based on diamagnetic nitrone or nitroso compounds which 'trap' a radical molecule, generating a paramagnetic spin adduct radical, which are detectable by ESR. These adducts have a specific 'signature' electron paramagnetic resonance spectrum based on the type of trapped radical. 5,5-dimethyl-1-pyrroline-N-oxide (DMPO) is the most common nitrone spin-trapping molecule. Hydroxylamine spin probes are different from spin-trap compounds; they do not bind the radicals but they form stable nitroxide when they are oxidised. The oxidation process requires the transfer of one electron. The most common electron is $\mathrm{O}^{-\bullet}$ (Dikalov et al., 2018; Kohno, 2010). ESR measurements provide information about the quantity, type, nature, surrounding environment and behaviour of unpaired electrons (Dikalov et al., 2018; Kohno, 2010). 


\subsection{5 | Oxidation-reduction potential}

Oxidation-reduction potential (ORP) is a new metric of redox equilibrium in a specified biological system. It measures the transfer of electrons from antioxidants (reductants) to oxidants. The MiOXSYS system comprises of an Analyzer consisting of an ultrahigh impedance electrometer (Rael, Bar-Or, Kelly, Carrick, \& Bar-Or, 2015) and a sensor with the reference and the working electrodes. To perform the test, a MiOXSYS sensor is placed on the sample port and $30 \mu \mathrm{l}$ of the sample is placed on the pre-inserted sensor (Figure 4). The sample fills the reference electrode on the sensor, completing the electrochemical circuit and the test then commences (Agarwal, Sharma, Roychoudhury, Du Plessis, \& Sabanegh, 2016). The test is based on the electrical conductance relative to an internal reference standard (Shapiro, 1972) according to Nernst equation.

$$
E(\mathrm{ORP})=E_{0}-R T / n F,
$$

Where $E$ is the Redox potential or ORP. $E_{0}$ is the standard potential of a redox system measured with respect to hydrogen electron, which is arbitrarily assigned an $E_{0}$ of 0 volts. $R=$ gas constant. $T=$ absolute temperature measured in degrees Kelvin. $n=$ number of moles of electrons transferred in the balanced equation for the reaction occurring in the cell. $F=$ Faradays constant.

This galvanostat-based system measures the static ORP (sORP) by measuring the voltage between the reference and the working electrode. MiOXSYS analyzer detects the voltage between the reference and the working electrodes at an interval of $0.5 \mathrm{~s}$, and the final ORP is calculated after $\sim 120 \mathrm{~s}$; an average of the last $10 \mathrm{~s}$ (or the last 20 readings) of the run. ORP results are expressed in millivolt $(\mathrm{mV})$ and are a snapshot of the balance of the redox system. ORP is manually normalised by dividing with the sperm concentration to give the adjusted ORP and expressed as $\mathrm{mV} / 10^{6} \mathrm{sperm} / \mathrm{mL}$ (Agarwal al., 2016). A cut-off of $1.34 \mathrm{mV} / 10^{6}$ cells $/ \mathrm{mL}$ was shown to discriminate samples based on semen quality (Agarwal et al., 2019). The advantages and of disadvantages of direct tests are listed in Table 2.

\section{2 | Indirect tests}

Indirect tests measure the concentration of antioxidants or the ROSinduced damage on cellular components such as lipids, DNA or proteins (Table 3). The advantages and disadvantages of indirect tests are shown in Table 3.

\subsection{1 | Endtz test}

Leucocytes, particularly polymorphonuclear neutrophils and macrophages, can produce significantly higher levels of ROS than abnormal spermatozoa and negatively affect sperm quality (Sharma, Pasqualotto, Nelson, \& Agarwal, 2001). White blood cells (WBC) can be differentiated from the immature germ cells by the peroxidase or the Endtz test (Shekarriz, Sharma, Thomas, \& Agarwal, 1995). The Endtz test is based on the evaluation of peroxidase, an enzyme present in the leucocyte granules which utilises $\mathrm{H}_{2} \mathrm{O}_{2}$ to oxidise the colourless substrate benzidine to an insoluble blue/brown derivative (Agarwal, Gupta, \& Sharma, 2016b). The test can differentiate peroxidase positive granulocytes such as neutrophils, polymorphonuclear leucocytes and macrophages from other germ cells (Endtz, 1974). The concentration of seminal leucocytes more than $1 \times 10^{6} \mathrm{WBC} / \mathrm{mL}$ of the sample is indicative of leucocytospermia (Cooper et al., 2010; World Health Organization, 2010).

\subsubsection{Measurement of lipid peroxidation products}

Unlike the somatic cells, the lipid bilayer in the plasma membrane of the human spermatozoa has high levels of PUFAs, which render them particularly susceptible to damage caused by excess ROS (Alvarez \& Storey, 1995; Mack, Everingham, \& Zaneveld, 1986; Poulos, Darin-Bennett, \& White, 1973). The breakdown of PUFAs to form lipid peroxides is known as lipid peroxidation (Halliwell \& Chirico, 1993). Lipid peroxidation generates end products such as
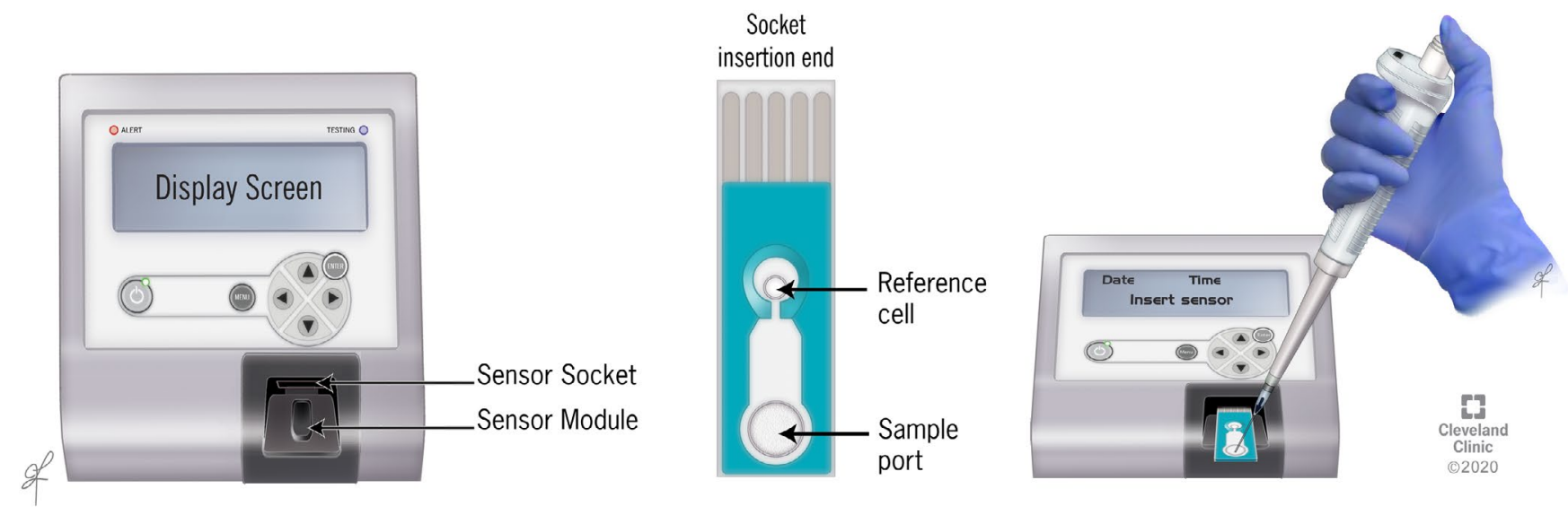

FIGURE 4 Measurement of ORP by the MiOXSYS system. (a) MiOXSYS analyzer showing the socket and the sensor module, (b) sensor showing the reference cell and the sample port where the sample is loaded and (c) loading of semen samples on the sample port of the sensor strip 
TABLE 2 Advantages and disadvantages of direct tests used to measure oxidative stress levels in the seminal plasma

\begin{tabular}{|c|c|c|}
\hline Test & Advantages & Disadvantages \\
\hline $\begin{array}{l}\text { Chemiluminescence } \\
\text { assay }\end{array}$ & $\begin{array}{l}\text { 1. Robust } \\
\text { 2. High sensitivity and specificity }\end{array}$ & $\begin{array}{l}\text { 1. Requires large sample volume } \\
\text { 2. Time-consuming } \\
\text { 3. Expensive equipment } \\
\text { 4. Cannot be used to measure ROS in frozen, viscous or } \\
\text { azoospermic samples } \\
\text { 5. Affected by changes in pH, centrifugation and the presence of } \\
\text { NADPH, cysteine, ascorbic acid or uric acid }\end{array}$ \\
\hline $\begin{array}{l}\text { Nitroblue } \\
\text { tetrazolium test }\end{array}$ & $\begin{array}{l}\text { 1. Readily available, inexpensive and has high } \\
\text { sensitivity } \\
\text { 2. Provides information about the differential } \\
\text { contribution of leucocytes and abnormal } \\
\text { spermatozoa in the production of ROS i.e. the } \\
\text { cellular origin of ROS in the sample } \\
\text { 3. It detects intracellular ROS, therefore it can be } \\
\text { used to discriminate the cellular source of ROS } \\
\text { in a heterogeneous cell population } \\
\text { 4. It can detect much lower concentrations of } \\
\text { (neutrophils) leucocytes (0.5 } \times 10^{6} / \mathrm{ml} \text { ) than he } \\
\text { established World Health Organization }(2010) \\
\text { cut-off for leucocytospermia }\left(1.0 \times 10^{6} / \mathrm{ml}\right)\end{array}$ & $\begin{array}{l}\text { 1. Presence of other cellular reductases may also reduce NBT } \\
\text { 2. Changes in the cellular content of various oxido-reductases may } \\
\text { also alter the rates of NBT reduction } \\
\text { 3. Specificity of ROS detected is questionable because the assay is } \\
\text { based on the reduction of NBT }\end{array}$ \\
\hline $\begin{array}{l}\text { Cytochrome } \mathrm{C} \\
\text { reduction test }\end{array}$ & $\begin{array}{l}\text { 1. It can quantify } \mathrm{O}_{2} \bullet-\text { released during the } \\
\text { respiratory burst of neutrophils or by isolated } \\
\text { enzymes } \\
\text { 2. Can measure high level of ROS production }\end{array}$ & $\begin{array}{l}\text { 1. Electrons donated from enzymes and other molecules can } \\
\text { directly reduce ferricytochrome c, and the resultant change in } \\
\text { absorbance is not specific for } \mathrm{O}_{2} \bullet- \\
\text { 2. Small quantities of } \mathrm{O}_{2} \bullet-\text { cannot be detected. The enzyme cannot } \\
\text { access to the intracellular space, so, only the extracellular ROS } \\
\text { fraction can be detected }\end{array}$ \\
\hline $\begin{array}{l}\text { Electron spin } \\
\text { resonance: } \\
\text { Spin-trap }\end{array}$ & $\begin{array}{l}\text { 1. Spin trap can differentiate between different } \\
\text { kinds of oxidative molecules } \\
\text { 2. In Hydroxylamine Spin, oxidation of hydroxyl } \\
\text { spin probes generates very stable nitroxide, } \\
\text { whose half-life can last hours }\end{array}$ & $\begin{array}{l}\text { 1. The spin-trap can be chemically modified by several enzymes } \\
\text { 2. Hydroxylamine Spin generates the same type of nitroxide, } \\
\text { therefore cannot discriminate between different oxidative } \\
\text { molecules. } \\
\text { 3. Probes are basic and at physiological } \mathrm{pH} \text { are partially inactive in } \\
\text { hydroxylamine spin } \\
\text { 4. Spontaneous oxidation of hydroxylamine increases in presence } \\
\text { of transition metal ions, therefore addition of Fe/Cu chelators to } \\
\text { solutions and buffer is required } \\
\text { 5. Adduct formation may be hampered by the scavenging action of } \\
\text { antioxidants in both techniques }\end{array}$ \\
\hline $\begin{array}{l}\text { Oxidation-reduction } \\
\text { potential }\end{array}$ & $\begin{array}{l}\text { 1. Simple, rapid (less than } 4 \text { min) method. } \\
\text { 2. Can be used in fresh and frozen samples without } \\
\text { any prior treatment } \\
\text { 3. High sensitivity and specificity } \\
\text { 4. Results are stable for up to } 2 \mathrm{hr} \text {. } \\
\text { 5. It estimates all the oxidants and antioxidants } \\
\text { present in a given sample (and not just one end } \\
\text { of the spectrum as do other tests that detect } \\
\text { oxidative stress directly or indirectly) } \\
\text { 6. ORP measurements are more stable than } \\
\text { standard semen analysis } \\
\text { 7. Can discriminate semen samples based on sperm } \\
\text { parameters or fertility status }\end{array}$ & $\begin{array}{l}\text { 1. Viscous samples are difficult to load and can affect the reading } \\
\text { 2. Cannot be used to analyse azoospermic samples }\end{array}$ \\
\hline
\end{tabular}

Abbreviations: NBT, nitroblue toluidine; ROS, reactive oxygen species; WHO, World Health Organization.

malondialdehyde (MDA), hydroxynonenal, 2-propenal (acrolein) and isoprostanes, all of which are indicators of OS (Dalle-Donne, Rossi, Colombo, Giustarini, \& Milzani, 2006). These unstable lipid peroxides decompose to form cytotoxic second messengers of oxidative stress such as MDA, 4-hydroxynonenal (4-HNE) and acrolein (ACR). These complex compounds modify relatively more stable DNA, lipids and proteins thereby altering sperm functions (Spickett, 2013; Zarkovic, 2003). 
TABLE 3 The advantages and disadvantages of indirect tests used to measure oxidative stress levels in the seminal plasma

\begin{tabular}{|c|c|c|}
\hline Test & Advantages & Disadvantages \\
\hline \multicolumn{3}{|l|}{ Lipid peroxidation } \\
\hline $\begin{array}{l}\text { HNE-HIS adduct } \\
\text { ELISA }\end{array}$ & 1. Rapid & 1. Cross reactivity \\
\hline DNA fragmentation & $\begin{array}{l}\text { 1. Multiple methods available - TUNEL, SCSA, Comet, SCD, and } \\
\text { 8-OHdG } \\
\text { 2. Comet assay is simple, versatile, sensitive and rapid assay and has } \\
\text { demonstrated some correlation with other assays such as SCSA and } \\
\text { TUNEL } \\
\text { 3. SCD test is simple, fast, and reproducible with comparable results } \\
\text { to those of the SCSA } \\
\text { 4. SCSA and TUNEL with flow cytometry is robust and sensitive } \\
\text { method } \\
\text { 5. TUNEL is a direct method that measures single- and double-strand } \\
\text { DNA breaks }\end{array}$ & $\begin{array}{l}\text { 1. Multiple cut-offs } \\
\text { 2. Inter- and intra-observer variability } \\
\text { 3. Lack of standardised reference value } \\
\text { 4. The 8-OHdG technique can itself cause } \\
\text { DNA oxidation interfering with basal level } \\
\text { 5. Cost of is a major concern in TUNEL and } \\
\text { SCSA assays }\end{array}$ \\
\hline
\end{tabular}

Abbreviation: 8-OHdG, 8-hydroxy-2-deoxyguanosine; ELISA, enzyme linked immunosorbent assay; MDA, malondialdehyde; OS, oxidative stress; OS, oxidative stress; PMN, polymorphonuclear neutrophils; ROS, reactive oxygen species; SCD, sperm chromatin dispersion; SCSA, sperm chromatin structure assay; TBA, thiobarbituric acid; TUNEL, terminal deoxynucleotidyl transferase dUTP nick-end labelling; WBC, white blood cell; WHO, World Health Organization.

\subsection{3 | Malondialdehyde measurement by thiobarbituric acid-reactive substances (TBARS) assay}

Malondialdehyde (MDA) is a reactive and mutagenic end product of lipid peroxidation in semen and can be measured using the TBA assay. In this assay, MDA (an aldehyde) derived from peroxides and unsaturated fatty acids binds with 2 molecules of TBA to form the MDA-TBA adduct which is measured colorimetrically or fluorometrically (Halliwell \& Chirico, 1993). MDA levels in the seminal plasma are 5-10-fold higher compared with those in the spermatozoa (Tavilani, Doosti, \& Saeidi, 2005). Low concentrations of sperm MDA can be detected by the sensitive high-performance liquid chromatography (Li, Shang, \& Chen, 2004; Shang et al., 2004), or by spectrofluorometry (Aitken, Harkiss, \& Buckingham, 1993).
Malondialdehyde levels show a significant positive correlation with seminal ROS levels in men with infertility, compared with fertile controls or normozoospermic individuals, highlighting its clinical utility (Hsieh, Chang, \& Lin, 2006; Tavilani et al., 2005). ROS-induced abnormalities in motility, sperm DNA integrity and sperm-oocyte fusion are associated with an increase in MDA concentration (Aitken, Clarkson, \& Fishel, 1989; Aitken et al., 1993).

Highly reactive aldehyde 4-hydroxynonenal (4-HNE), an end product of lipid peroxidation, is a second messenger of free radicals and a signalling molecule. HNE-protein adducts are quantified using ELISA with a monoclonal antibody (Borovic, Rabuzin, Waeg, \& Zarkovic, 2006). 4-HNE may impair sperm capacitation by targeting the protein kinase A affecting the tyrosine phosphorylation pathway and thus reducing sperm motility (Baker et al., 2015). 
Peroxidation of arachidonic acid results in the formation of isoprostanes which are a series of prostaglandin F2-like compounds. They can be determined by quantification of the amount of F2isoprostanes (F2-IsoP) present in the semen (Signorini, Comporti, \& Giorgi, 2003; Signorini et al., 2008).

8-iso-PGF $2 \alpha$ is determined by immunocytochemical staining with polyclonal antibody and visualised under fluorescence microscope. Significantly higher levels of free 8 -iso-PGF $2 \alpha$ levels in the seminal plasma are reported in infertile men when compared with normozoospermic men (Khosrowbeygi \& Zarghami, 2007). In addition, it negatively correlates with MDA and seminal SOD activity in normozoospermic men (Tavilani et al., 2008).

\subsection{4 | Measurement of total antioxidants in seminal plasma}

Total antioxidant capacity (TAC) is the measure of the reducing capacity of seminal antioxidants against an oxidative reagent. It evaluates enzymatic antioxidants in the seminal plasma such as superoxide dismutase, catalase, glutathione peroxidase and nonenzymatic antioxidants such as $\alpha$-tocopherol (vitamin E), ascorbate (vitamin C), $\beta$-carotene (vitamin A), folic acid (vitamin B9), ferritin and carnitines, $\mathrm{N}$-acetyl L-cysteine, coenzyme Q10, ceruloplasmin, selenium, L-arginine, urate and zinc (Henkel, Sandhu, Agarwal, \& A., 2019; Mahfouz, Sharma, Lackner, Aziz, \& Agarwal, 2009a; Mahfouz, Sharma, Said, Erenpreiss, \& Agarwal, 2009b). Over the years, a number of assays have been proposed which include colorimetric, spectrophotometric and chemiluminescence-based assays.

In the colorimetric assay, the clear seminal plasma is used with the TAC kit. The principle of the assay is based upon the ability of all antioxidants in the seminal plasma to inhibit the oxidation of the 2,2'-azino-di-[3-ethylbenzthiazoline sulphonate] (ABTS) to ABTS+. (Agarwal Gupta, \& Sharma, 2016a, 2016b, 2016c, 2016d). The antioxidants in the seminal plasma suppress the absorbance at $750 \mathrm{~nm}$; this suppression is proportional to the concentration of antioxidant. Trolox (6-hydroxy-2, 5, 7, 8-tetramethylchroman-2-carboxylic acid), a water-soluble tocopherol analogueis used as the standard. The amount of antioxidant in a given sample is measured by a colorimeter (Agarwal, Gupta, \& Sharma, 2016a, 2016b, 2016c, 2016d). Antioxidant level is reported as micromoles of Trolox equivalent. The normal antioxidant concentration in a sample is $>1,950$ micromoles of Trolox equivalent (Figure 5). Lower TAC values reflect increased OS or poor ROS scavenging ability. Although this test is rapid, it does not measure any specific enzymatic antioxidants (Roychoudhury, Sharma, Sikka, \& Agarwal, 2016).

\subsection{5 | ROS-TAC score}

ROS-TAC score is derived from the individual values obtained for ROS levels and seminal TAC values. Principal component analysis

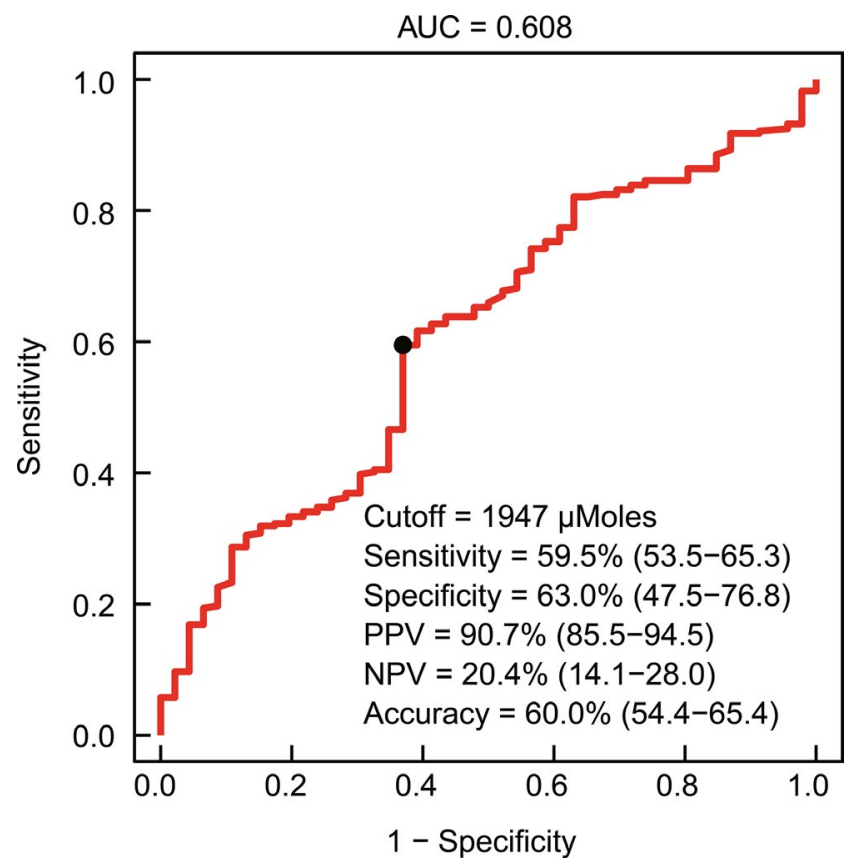

FIGURE 5 Total antioxidant capacity receiver operating characteristics (ROC) curve showing the area under curve (AUC), cut-off, sensitivity, specificity, positive predictive value, negative predictive value and accuracy of the assay

is used to analyse the standardised values of ROS and TAC. The linear combinations or weighted sums accounts for the most variability among correlated variables. The ROS and TAC values of the control samples are used to generate a reference point (Sharma, Pasqualotto, Nelson, Thomas, \& Agarwal, 1999).

Patients with high OS have a lower ROS-TAC score than do fertile healthy men (Sharma et al., 1999). ROS-TAC score can discriminate between fertile and infertile men better than ROS or TAC alone (Sharma et al., 1999). Significantly lower ROS-TAC scores than controls are seen in infertile men with male factor or idiopathic infertility. Furthermore, significantly higher ROS-TAC scores are seen in men with male factor diagnoses who are able to initiate a successful pregnancy compared to those who do not. Male partners of couples who achieve pregnancy have ROS-TAC scores similar to those of the controls. ROS-TAC score may help identify patients with a clinical diagnosis of male infertility who are likely to achieve a pregnancy over a period of time (Pasqualotto, Sharma, Pasqualotto, \& Agarwal, 2008).

\subsection{6 | Measurement of sperm DNA fragmentation}

OS and apoptosis contribute to sperm DNA fragmentation (SDF; Henkel et al., 2005; Mahfouz et al., 2010; Mahfouz et al., 2009a; Mahfouz et al., 2009b; Sakkas et al., 1999). In addition, advanced age, cigarette smoking, chemotherapy, radiation, cancer, varicocele, leucocytospermia and elevated levels of ROS all contribute to SDF (Agarwal, Varghese, \& Sharma, 2009; Zini, Boman, Belzile, \& Ciampi, 2008). Several authors have demonstrated high amount 

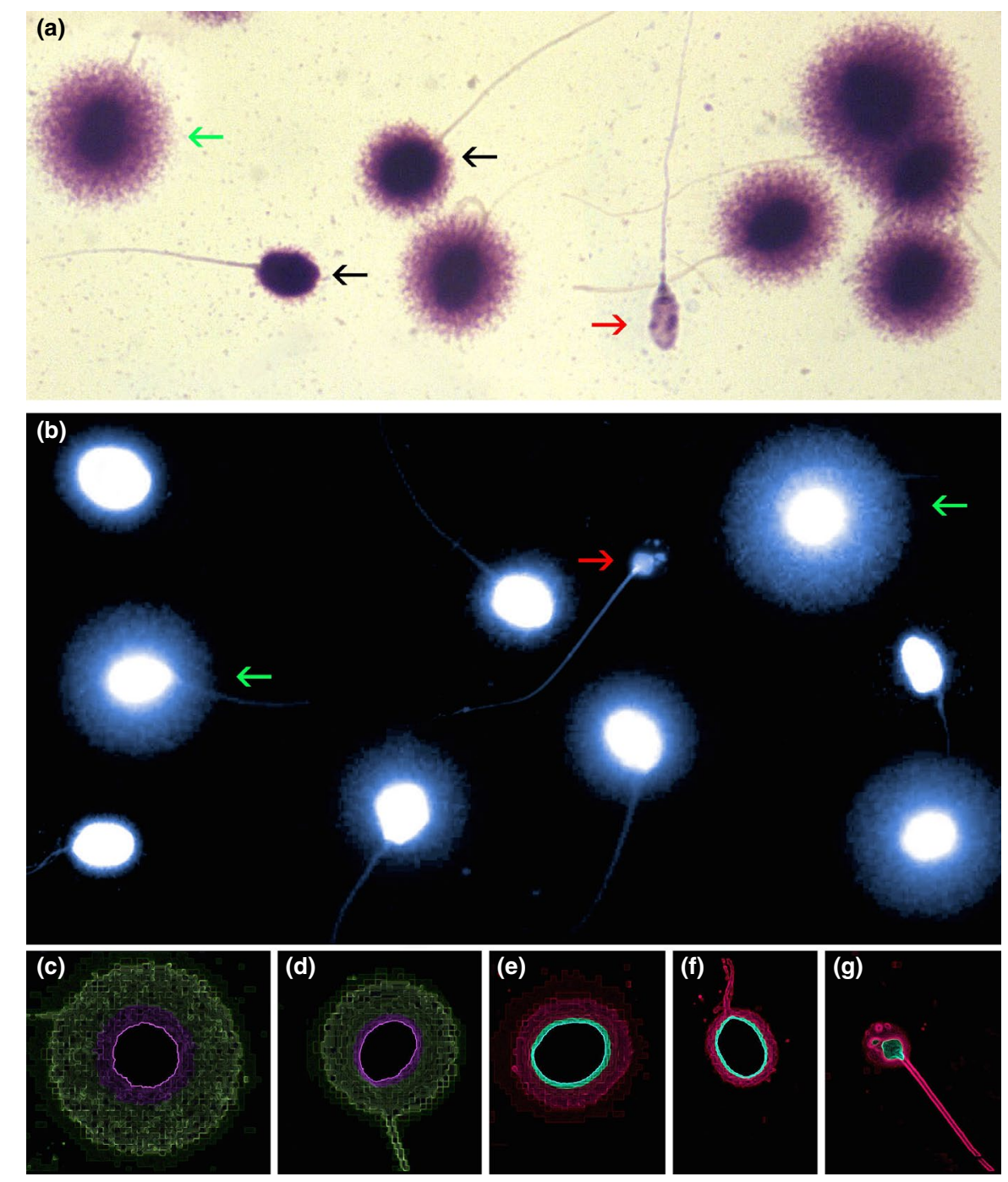

FIGURE 6 Assessment of sperm DNA fragmentation using the sperm chromatin dispersion (SCD) test. Nucleoids from human spermatozoa obtained with the improved SCD procedure (Halosperm, Halotech DNA, SL, Madrid, Spain) under (a) bright-field microscopy and Wright's stain (b) under fluorescence microscopy and DAPI staining. Green arrows target spermatozoa containing a normal DNA molecule. Red arrows target a highly fragmented spermatozoon (degraded spermatozoa). (c-g) Electronic filtered images showing a series of nucleoids with different levels of sperm DNA damage. Nucleoids with highlighted core delineation in green correspond to (c) large (d) and medium halos of dispersed chromatin representing a normal DNA molecule. Nucleoids in red are spermatozoa containing fragmented DNA and are represented by (e) small or (f) no halos of dispersed chromatin and (g) degraded spermatozoa. Bright-field and fluorescence microphotographs were obtained using a motorised fluorescence microscope controlled with software for automatic scanning and image digitisation (Leica Microsystems). The microscope was equipped with a Leica EL6000 metal halide fluorescence light source and Plan-Fluotar $60 \times$ objectives with three independent filter blocks (DAPI-5060B; FITC-3540B and TRITC-A; Semrock). A charge-coupled device (Leica DFC350 FX, Leica Microsystems) was used for image capture. (Courtesy of Prof. Jaime Gonsálvez, Madrid, Spain)

of impaired DNA integrity in infertile men (Garolla et al., 2015; Majzoub, Agarwal, Cho, \& Esteves, 2017; Ribas-Maynou et al., 2013).

The more commonly used tests are summarised below.

\section{Sperm chromatin dispersion assay}

In this assay, spermatozoa are treated with an acid solution prior to lysis buffer, spermatozoa with fragmented DNA produce a minimal halo (Fernández et al., 2003). When spermatozoa with nonfragmented DNA are immersed in an agarose matrix and directly exposed to lysing solutions, the resulting deproteinised nuclei (nucleoids) show a central (core) and peripheral halo of dispersed DNA caused by release of DNA loops. These halos can be observed either by bright-field microscopy using Wright's stain or fluorescent

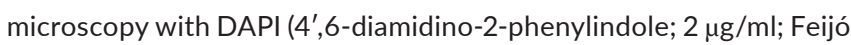
\& Esteves, 2014; Fernández et al., 2005; Figure 6). SDF is negatively correlated with fertilisation rates and embryo quality in IVF/ICSI. However, SDF was not related with clinical pregnancy rates or births (de la Calle et al., 2008; Muriel et al., 2006).

\section{Comet assay or Single-cell gel electrophoresis}

The comet assay, also called the single-cell gel electrophoresis, is based on the electrophoretic migration of cleaved fragments of 
DNA. It is based on the principle that the negatively charged DNA loops or fragments are drawn through an agarose gel in response to an electrical field. Neutral comet assay detects only double-stranded DNA breaks, whereas alkaline comet assay detects both single- and double-stranded DNA breaks (Singh et al., 1989; Singh, McCoy, Tice, \& Schneider, 1988).

\section{Terminal deoxynucleotidyl transferase-mediated deoxyuridine} triphosphate-nick end labelling (TUNEL) assay

Terminal deoxynucleotidyl transferase-mediated deoxyuridine triphosphate-nick end labelling or the TUNEL assay uses a template-independent DNA polymerase enzyme called terminal deoxynucleotidyl transferase (TdT), which adds deoxyribonucleotides to $3^{\prime}$ hydroxyl $(\mathrm{OH})$ end of DNA breaks (Figure 7). TdT enzyme adds fluorescent deoxyuridine triphosphate (dUTP) to the free 3'-OH break-ends of DNA and are quantified by flow cytometry (Agarwal et al., 2016c, 2016d; Gupta, Sharma, \& Agarwal, 2017; Sharma, Ahmad, Esteves, \& Agarwal, 2016; Sharma et al., 2010). TUNEL assay measures both single- and double-strand DNA fragmentation.

DNA fragmentation can be measured using an APO-DIRECT Kit (BD Pharmingen ${ }^{\mathrm{TM}}$ ). The percentage of negative (TUNEL-negative) and positive (TUNEL-positive) cells is calculated on the flow cytometer software (Figure $8 \mathrm{a}-\mathrm{e}$ ). The reference value of $16.7 \%$ has been established for DNA fragmentation (Figure 9a). Significantly higher levels of SDF are seen in infertile men compared with control (healthy men) (Agarwal et al., 2016a; Agarwal et al., 2016b; Agarwal et al., 2016c; Agarwal et al., 2016d; Gupta et al., 2017; Sharma et al., 2016) (Figure 9b).

\section{Sperm Chromatin Structure Assay (SCSA)}

Impaired sperm chromatin is susceptible to partial DNA denaturation induced in situ either with heat or acid treatment. This change in the conformation following acid or heat treatment is determined by measuring the metachromatic shift of acridine orange fluorescence from green (native DNA) to red (denatured DNA). The extent of SDF measured as \% of sperm with fragmented DNA is called DNA fragmentation index or DFI (Evenson, 2016).

$$
\text { Percent DFI }=\frac{\text { Red fluorescence }}{\text { Total }(\text { red }+ \text { green }) \text { fluorescence }} \times 100 \text {. }
$$

Intact spermatozoa (native double stranded) fluorescent green whereas those with fragmented DNA (single-stranded DNA) fluoresce red. SCSA is sensitive and robust assay that accurately measures the percentage of DNA-damaged spermatozoa. A DFI of $30 \%$ can differentiate between fertile and infertile samples (Evenson, Larson, \& Jost, 2002; Evenson \& Wixon, 2006).

\section{8-hydroxy-2-deoxyguanosine (8-OHdG)}

8-hydroxy-2-deoxyguanosine (8-OHdG) assay measures levels of 8-hydroxy-2-deoxyguanosine, which is a byproduct of oxidantinduced DNA damage in the spermatozoa. It can be detected at a

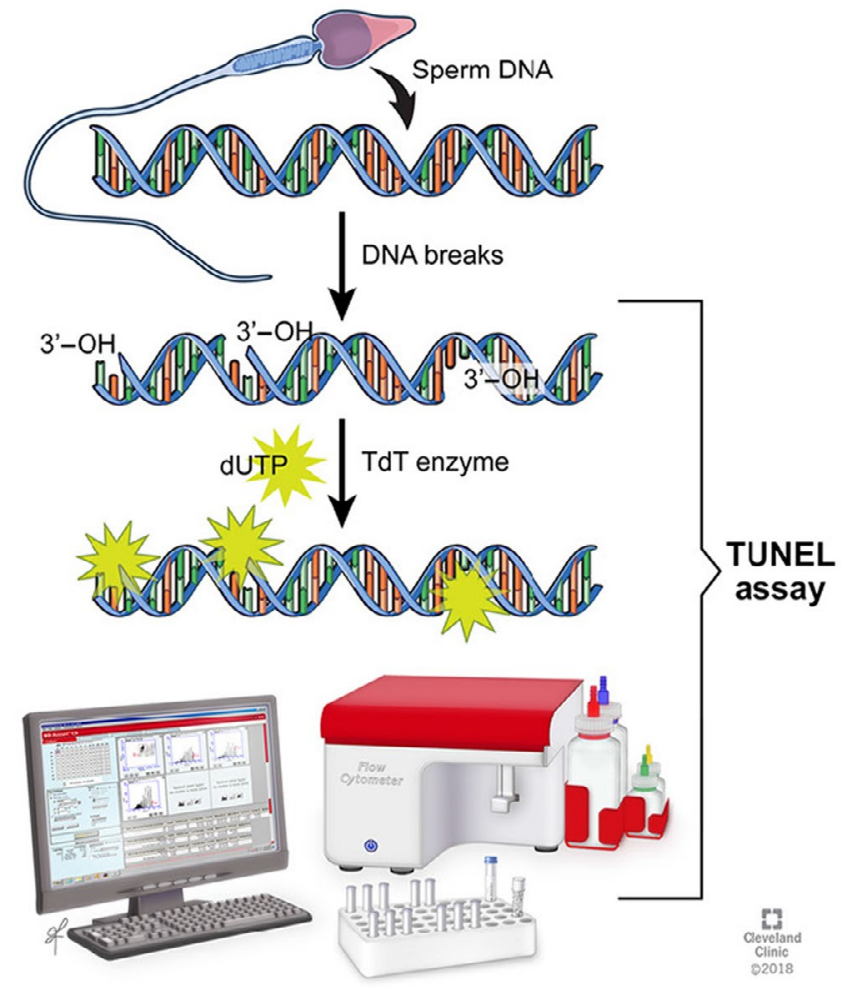

FIGURE 7 Schematic of the DNA staining principal by the TUNEL assay

single-cell level using 8-OHdG specific antibodies producing fluorescence that can be visualised by flow cytometry or fluorescent microscopy (Vorilhon et al., 2018).

8-OHdG provides the most direct evidence that SDF due to oxidative stress is involved in male infertility. 8-OHdG is inversely associated with sperm concentration (Kodama, Yamaguchi, Fukuda, Kasai, \& Tanaka, 1997). SDF measured by 8-OHdG and TUNEL assay are highly correlated with each other (Aitken, De luliis, Finnie, Hedges, \& McLachlan, 2010). In addition, 8-OHdG levels are highly correlated with the extent of disruption of chromatin remodelling (De luliis et al., 2009).

\subsection{7 | Detection of post-translational modifications of proteins}

Spermatozoa do not have an active protein synthesis; however, a dynamic change in protein profile occurs as a result of acquisition of new proteins through vesicular transport and several post-translational modifications (PTMs) (Samanta, Swain, Ayaz, Venugopal, \& Agarwal, 2016). PTMs are chemical alterations in the protein structure that are typically catalysed by substrate-specific enzymes. These modifications regulate the stability, distribution and function of proteins. Post-translational modifications increase the diversity of the proteome, and specific modifications are introduced that can be translated into functional changes in the affected proteins (Brohi \& Huo, 2017). 
(a)

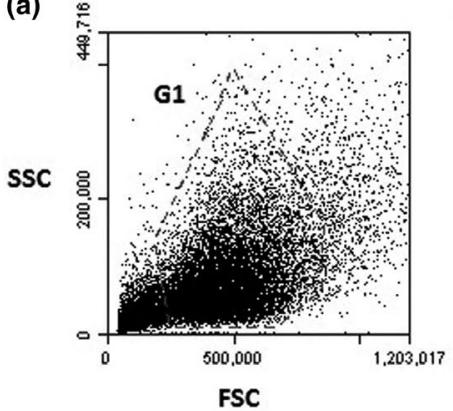

(b)

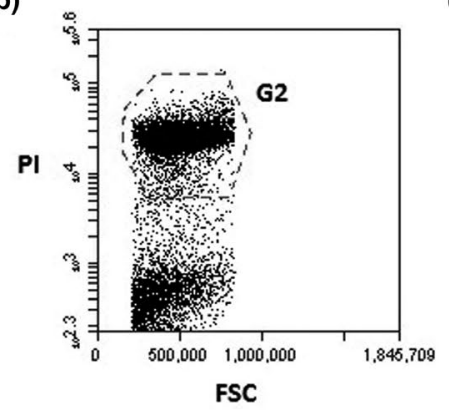

(c)

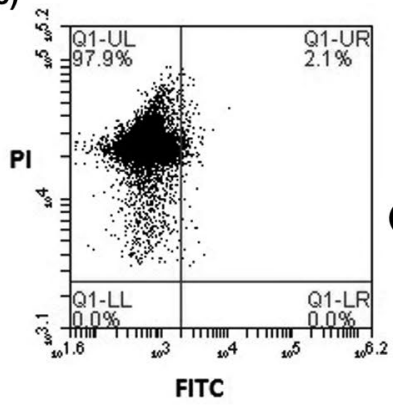

(d)

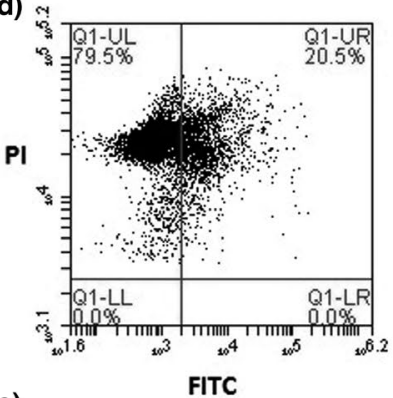

(e)

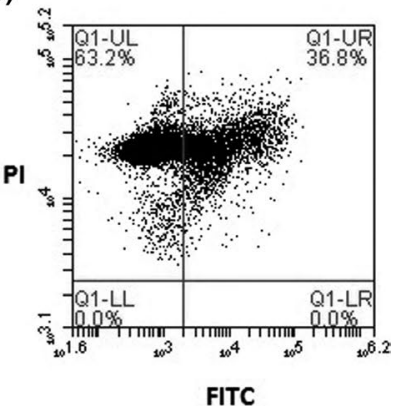

FIGURE 8 Example of Accuri C6 Workspace and gating strategy used in both laboratories for TUNEL data analysis. (a) FSC/SSC plot showing the gate used for spermatozoa selection (G1). (b) PI/FSC plot with gating for PI positivity (G2). (c) PI/FITC plot of negative control sample (TdT enzyme omitted). (d) PI/FITC plot of standard sample. (e) PI/FITC plot of positive control sample. FSC, forward scatter; SSC, side scatter; PI, propidium iodide fluorescence; FITC, fluorescein isothiocyanate fluorescence; Q1-UL, upper left quadrant; Q1-UR, upper right quadrant; Q1-LL, lower left quadrant; Q1-LR, lower right quadrant

FIGURE 9 Receiver operator characteristic (ROC) curve showing (a) TUNEL cut-off and the area under the curve. Values within the parentheses represent the $95 \%$ confidence interval and (b) distribution of TUNEL values between controls and infertile men
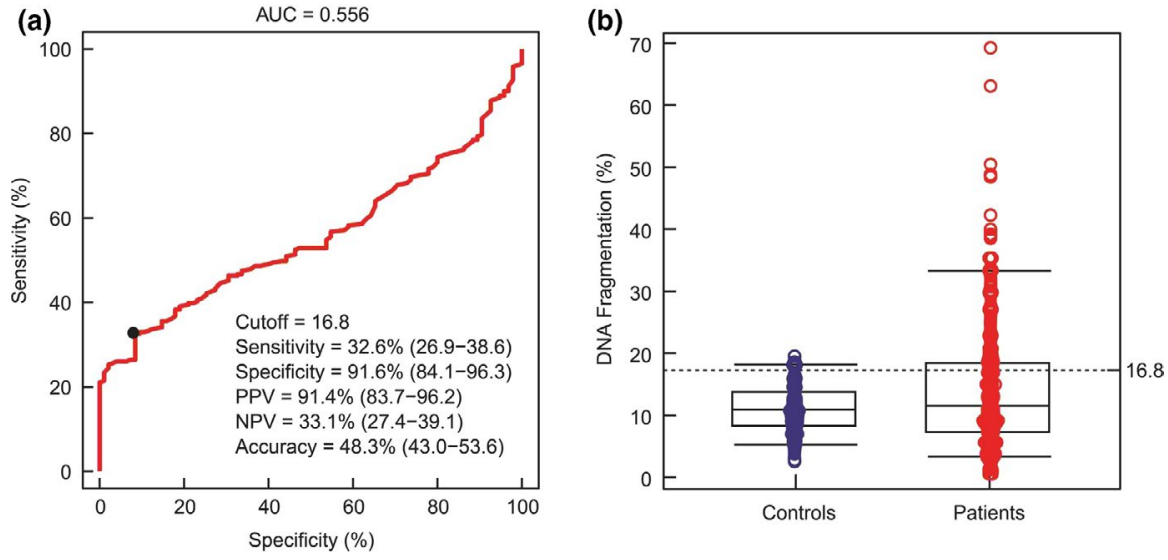

Failure to control complex molecular processes can be detrimental or lethal for the cell. There are about 300 reported covalent modifications and of these modifications, the most common are phosphorylation, nitrosylation, glycosylation, methylation, lipid modification, ubiquitination and acetylation (Zhou et al., 2015). Protein modifications by ROS results in formation of end products such as s-glutathione, nitrotyrosine and reactive carbonyls (Dalle-Donne et al., 2006; Radi, 2004; Samanta et al., 2016). These modifications result in altered protein functions that can be measured by ELISA using protein-specific antibodies (Agarwal, Sharma, et al., 2015; Esteves et al., 2015; Radi, 2004). PTMs are overexpressed in the seminal plasma proteome of men with high levels of ROS when compared to fertile control group (Agarwal, Ayaz, et al., 2015).

\subsection{8 | Proteomic analysis of spermatozoa and seminal plasma}

Protein alterations present both in the spermatozoa and seminal plasma vary at different levels of OS (Agarwal, Ayaz, et al., 2015; Sharma et al., 2013). Exposure of seminal proteome to different amounts of OS showed that proteins involved in biomolecule metabolism, protein folding and degradation were differentially modulated in infertile patients when compared to fertile controls (Agarwal, Ayaz, et al., 2015; Sharma et al., 2013). Exposure of the sperm proteome to different levels of OS in infertile men showed differentially expressed proteins (DEPs) exhibiting distinct reproductive functions (Ayaz et al., 2015). These modified DEPs can be identified by proteomic and bioinformatic analysis and validated as a 
potential biomarkers of ROS by Western blot analysis using proteinspecific antibodies or ELISA followed by immunochemistry. Most commonly employed techniques to detect sperm-specific protein alterations utilising proteomic analysis include 2D polyacrylamide gel electrophoresis (2D-PAGE), differential in gel electrophoresis (DIGE) and liquid chromatography-mass spectrometry (LC-MS) or liquid chromatography-tandem mass spectrometry (LC-MS/MS). Global proteomic analysis involves analysis of pooled or individual test samples of spermatozoa or seminal plasma (Agarwal et al., 2016; Ayaz et al., 2015; Samanta et al., 2016). The quantification and identification of a target protein can be achieved by Western blot analysis, (Agarwal et al., 2016) or by immunocytochemistry (Engvall, Jonsson, Jonsson, \& Perlmann, 1971; Mathews, Plaisance, \& Kim, 2009; Samanta et al., 2018).

\section{3 | Measurement of intracellular ROS}

Intracellular ROS is measured by flow cytometry using two specific dyes 2',7' dichlorofluorescin diacetate (DCFDA) and dihydroethidium or hydroethidine (DHE). DCFDA is deacetylated within the sperm cell and oxidised by ROS to form 2',7'-dichlorofluorescein (DCF), a fluorescent green compound. It measures peroxyl, alkoxyl, $\mathrm{NO}_{2}{ }^{\bullet}$, carbonate $\left(\mathrm{CO}_{3}{ }^{-}\right.$) ) and $\mathrm{OH}^{\bullet}$ radicals (Mupfiga et al., 2013). Peroxynitrite, hypochlorous acid and $\mathrm{OH} \bullet$ in defective spermatozoa can also oxidise DCF and significantly contribute to the positive signals (Mahfouz et al., 2009a; Mahfouz et al., 2009b; Myhre, Andersen, Aarnes, \& Fonnum, 2003). Cellular production of $\mathrm{O}_{2}{ }^{\bullet-}$ can be visualised by oxidation of $\mathrm{O}_{2}^{\bullet-}$ by DHE and results in hydroxylation and formation of 2-hydroxyethidium with red florescence emission at 488 nm (Henkel et al., 2003; Rothe \& Valet, 1990; Zielonka, Vasquez-Vivar, \& Kalyanaraman, 2008). Furthermore, viable cells generating ROS can be measured by DHE along with a vitality marker (SYTOX green; De luliis, Wingate, Koppers, McLaughlin, \& Aitken, 2006; Mahfouz et al., 2009a; Mahfouz et al., 2009b). Fluorescent techniques have a higher specificity, accuracy, sensitivity and reproducibility (Gosalvez et al., 2017).

\section{4 | TYPES OF SAMPLES USED FOR ROS MEASUREMENT}

ROS levels can be measured in unprocessed seminal ejaculate or semen sample processed by simple wash, swim up, migration-sedimentation or density-gradient centrifugation (Benjamin, Sharma, Moazzam, \& Agarwal, 2012).

\subsection{Neat (or unprocessed) seminal ejaculate}

Levels of ROS in the neat sample or unprocessed samples are reflective of the ROS produced by spermatozoa and all the other cells present in the seminal ejaculate. These include secretions from prostate, seminal vesicles and other accessory glands and cellular components such as round cells, leucocytes and epithelial cells.

\section{2 | Sperm wash}

In this method, culture medium is added to the ejaculate and the sample is centrifuged twice and the seminal plasma is removed. However, this does not eliminate other cells such as leucocytes, round cells and debris. The centrifugation force $(<500 \mathrm{~g})$ and numbers of centrifugation steps must be kept to a minimum in order to reduce the ROS-induced damage by nonviable, morphologically abnormal spermatozoa and leucocytes (Björndahl et al., 2010; Ren, Sun, Ku, Chen, \& Wu, 2004).

\section{3 | Swim-up}

In the conventional swim-up technique, $0.5 \mathrm{ml}$ of post-liquefaction sample is gently placed at the bottom of a tube and layered with about $2 \mathrm{ml}$ of the sperm wash medium. Swim up can also be performed using a prewashed sperm pellet obtained by low speed centrifugation and placing the tube gently at an angle of $45^{\circ}$ and incubating for $60 \mathrm{~min}$. Clear supernatant is carefully aspirated using sterile pipette and centrifuged to obtain a highly motile, morphologically normal intact spermatozoa enriched in the absence of other cells, proteins and debris within the supernatant (Agarwal et al., 2016d). Swim-up method is inexpensive; however, the sperm recovery is relatively low and only 5 to 10 per cent of sperm cells are retrieved.

\section{4 | Migration-sedimentation}

Migration-sedimentation is usually used for samples with low motility. It uses the swim-up technique and the natural settling of spermatozoa due to gravity. It is performed in special tubes called Tea-Jondet tubes (Mortimer, 1994). The amount of ROS produced is not very significant as this technique is gentle (Henkel \& Schill, 2003).

\section{5 | Discontinuous density gradient}

Density gradient separation is a process where the cells are separated based on their density, motility and the centrifugation speed. The gradient is a colloidal suspension of silica particles, which are stabilised with covalently bonded hydrophilic Silane in HEPES. Two distinct gradients are used and consist of a lower phase or $80 \%$ gradient and an upper phase or a $40 \%$ gradient. Two $\mathrm{mL}$ of lower phase is placed in a $15 \mathrm{ml}$ graduated centrifuge tube and $2 \mathrm{ml}$ of upper phase is placed gently on the lower phase. Up to $2 \mathrm{ml}$ of a completely liquefied semen sample is gently layered on top and centrifuged at 
$300 \mathrm{~g}$ for $20 \mathrm{~min}$. The highly purified motile sperm cells are enriched in the soft pellet at the bottom. (Agarwal et al., 2016a, 2016b, 2016c, 2016d). Two $\mathrm{mL}$ of sperm washing medium (modified HTF with $5.0 \mathrm{mg} / \mathrm{ml}$ human albumin) is used to wash the gradient. The sample is centrifuged at $300 \mathrm{~g}$ for $7 \mathrm{~min}$. The final pellet is resuspended in $0.5 \mathrm{ml}$ of the sperm washing medium. This method allows for the enrichment of mature and motile spermatozoa. Sperm recovery rates of $30 \%-80 \%$ can be achieved depending on the quality of the initial semen sample as well as the technical skill of the operator.

\section{5 | FACTORS AFFECTING THE ROS MEASUREMENT}

Semen samples with a higher concentration of morphologically abnormal spermatozoa with excessive presence of cytoplasm will produce higher levels of ROS (De Lamirande \& Gagnon, 1995; Plante, de Lamirande, \& Gagnon, 1994). The measurement of intracellular ROS will also be affected by the scavenging action of the antioxidants present in the seminal plasma, producing a result lower than the actual ROS concentration at a given time point. Hence, it would be ideal to separate the cells from the reactants-containing seminal fluid. The time of assessment is important wherein viable samples have higher oxidative damage when exposed to ROS for longer periods (Bourne, Archer, Edgar, \& Gordan Baker, 2009). The semen samples undergo sperm preparation post-liquefaction by various methods to obtain a rich population of morphologically normal and highly motile spermatozoa. Paradoxically, sperm preparation techniques that include centrifugation also increase the ROS production.

\section{6 | LIMITATIONS OF CURRENT OXIDATIVE STRESS MARKERS}

Enzymes and other molecules can modify the reagents used in assays such as cytochrome $C$ reduction test, electron spin resonance and NBT reducing the accuracy of the results. Lipid peroxidation crossreactivity is a drawback with HNE-HIS adduct ELISA, whereas the reagent used in MDA-TBARS is not specific for MDA. Most of the above described assays require large sample volumes, specific reagents and expensive instrumentation and are laborious. The majority of these assays measure only a single parameter and do not provide a comprehensive assessment of OS. Sperm preparation performed prior to the assay can further enhance the ROS production as a result of repeated centrifugation. Measurement of ORP overcomes majority of these limitations being rapid and cost-effective and can be measured in fresh and frozen samples without any prior sample preparation.

\section{7 | CONCLUSION}

Although OS has a central role in male infertility, a physiological level is required for normal sperm function. Both direct and indirect methods for measuring OS are available, but establishing the reference ranges of these markers is challenging. ORP provides a global value of redox potential and can help categorise men with normal, high or low OS. There is ongoing need for more efficient and safer technique that avoids the excessive production of ROS during the preparation of spermatozoa.

\section{Take Home Message}

1. There is no 'gold standard' for the evaluation of oxidative stress.

2. The direct and indirect tests for the detection of oxidative stress present different strengths and weakness, which limit their use in clinics.

3. There is an urgent need for laboratory tests that are novel, simple and provide a comprehensive picture of oxidative status in the infertile male.

4. ORP represents a promising marker to be used in the andrology laboratory, as it provides an evaluation of the global redox status, unlike other techniques which assess only the oxidants or the antioxidants.

\section{ORCID}

Kathy A. Robert (D) https://orcid.org/0000-0002-9448-6341

Rakesh Sharma (iD https://orcid.org/0000-0002-9664-6978

Ralf Henkel iD https://orcid.org/0000-0003-1128-2982

Ashok Agarwal iD https://orcid.org/0000-0003-0585-1026

\section{REFERENCES}

Agarwal, A., Ahmad, G., \& Sharma, R. (2015). Reference values of reactive oxygen species in seminal ejaculates using chemiluminescence assay. Journal of Assisted Reproduction and Genetics, 32(12), 17211729. https://doi.org/10.1007/s10815-015-0584-1

Agarwal, A., Ayaz, A., Samanta, L., Sharma, R., Assidi, M., Abuzenadah, A. M., \& Sabanegh, E. (2015). Comparative proteomic network signatures in seminal plasma of infertile men as a function of reactive oxygen species. Clinical Proteomics, 12(1), 23. https://doi.org/10.1186/ s12014-015-9094-5

Agarwal, A., Gupta, S., \& Sharma, R. (2016a). Antioxidant measurement in seminal plasma by TAC Assay. Chapter 23. In A. Agarwal, S. Gupta, \& R. Sharma (Eds.), Andrological evaluation of male infertility: a laboratory guide (pp. 171-180). New York, NY: Springer Publishing.

Agarwal, A., Gupta, S., \& Sharma, R. (2016b). Leukocytospermia quantitation (ENDTZ) test. Chapter 7. In A. Agarwal, S. Gupta, \& R. Sharma (Eds.), Andrological evaluation of male infertility: A laboratory guide (pp. 69-72). New York, NY: Springer Publishing.

Agarwal, A., Gupta, S., \& Sharma, R. (2016c). Measurement of DNA fragmentation in spermatozoa by TUNEL assay using bench top flow cytometer. Chapter 24. In A. Agarwal, S. Gupta, \& R. Sharma (Eds.), Andrological evaluation of male infertility: A laboratory guide (pp. 181). New York, NY: Springer Publishing.

Agarwal, A., Gupta, S., \& Sharma, R. (2016d). Sperm preparation for intrauterine insemination (IUI) by swim-up method. Chapter 15. In A. Agarwal, S. Gupta, \& R. Sharma (Eds.), Andrological evaluation of male infertility: A laboratory guide (pp. 109-112). New York, NY: Springer Publishing.

Agarwal, A., Panner Selvam, M. K., Arafa, M., Okada, H., Homa, S., Killeen, A., ... Sikka, S. (2019). Multi-center evaluation of oxidation-reduction potential by the MiOXSYS in males with abnormal semen. Asian Journal of Andrology, 21(6), 565-569. https://doi.org/10.4103/aja.aja_5_19

Agarwal, A., Parekh, N., Panner Selvam, M. K., Henkel, R., Shah, R., Homa, S. T., ... Harlev, A. (2019). Male oxidative stress infertility 
(MOSI): Proposed terminology and clinical practice guidelines for management of idiopathic male infertility. The World Journal of Men's Health, 37(3), 296-312. https://doi.org/10.5534/ wjmh.190055

Agarwal, A., \& Sengupta, P. (2020). Oxidative stress and its association with male infertility. In S. Parekattil, S. Esteves, \& A. Agarwal (Eds.), Male infertility (pp. 57-68). Cham: Springer.

Agarwal, A., Sharma, R., Durairajanayagam, D., Ayaz, A., Cui, Z., Willard, B., ... Sabanegh, E. (2015). Major protein alterations in spermatozoa from infertile men with unilateral varicocele. Reproductive Biology and Endocrinology, 13(1), 8. https://doi.org/10.1186/s1295 8-015-0007-2

Agarwal, A., Sharma, R. K., Nallella, K. P., Thomas Jr., A. J., Alvarez, J. G., \& Sikka, S. C. (2006). Reactive oxygen species as an independent marker of male factor infertility. Fertility and Sterility, 86(4), 878-885. https://doi.org/10.1016/j.fertnstert.2006.02.111

Agarwal, A., Sharma, R., Roychoudhury, S., Du Plessis, S., \& Sabanegh, E.. (2016). MiOXSYS: A novel method of measuring oxidation reduction potential in semen and seminal plasma. Fertility and Sterility, 106(3), 566-573. https://doi.org/10.1016/j.fertn stert.2016.05.013

Agarwal, A., Sharma, R., Samanta, L., Durairajanayagam, D., \& Sabanegh, E. (2016). Proteomic signatures of infertile men with clinical varicocele and their validation studies reveal mitochondrial dysfunction leading to infertility. Asian Journal of Andrology, 18(2), 282-291. https://doi.org/10.4103/1008-682X.170445

Agarwal, A., Varghese, A. C., \& Sharma, R. K. (2009). Markers of oxidative stress and sperm chromatin integrity. Molecular Endocrinology, 590, 377-402.

Agarwal, A., Virk, G., Ong, C., \& du Plessis, S. S. (2014). Effect of oxidative stress on male reproduction. The World Journal of Men's Health, 32(1), 1-17. https://doi.org/10.5534/wjmh.2014.32.1.1

Aitken, J. R., Clarkson, J. S., \& Fishel, S. (1989). Generation of reactive oxygen species, lipid peroxidation, and human sperm function. Biology of Reproduction, 41(1), 183-197. https://doi.org/10.1095/biolreprod 41.1.183

Aitken, R. J. (2017). Reactive oxygen species as mediators of sperm capacitation and pathological damage. Molecular Reproduction and Development, 84(10), 1039-1052. https://doi.org/10.1002/ $\operatorname{mrd} .22871$

Aitken, R. J., \& Baker, M. A. (2013). Oxidative stress, spermatozoa and leukocytic infiltration: Relationships forged by the opposing forces of microbial invasion and the search for perfection. Journal of Reproductive Immunology, 100(1), 11-19. https://doi.org/10.1016/j. jri.2013.06.005

Aitken, R. J., \& Curry, B. J. (2011). Redox regulation of human sperm function: From the physiological control of sperm capacitation to the etiology of infertility and DNA damage in the germ line. Antioxidants \& Redox Signaling, 14(3), 367-381. https://doi.org/10.1089/ars.2010.3186

Aitken, R. J., De luliis, G. N., Finnie, J. M., Hedges, A., \& McLachlan, R. I. (2010). Analysis of the relationships between oxidative stress, DNA damage and sperm vitality in a patient population: Development of diagnostic criteria. Human Reproduction, 25(10), 2415-2426. https:// doi.org/10.1093/humrep/deq214

Aitken, R. J., Gibb, Z., Baker, M. A., Drevet, J., \& Gharagozloo, P. (2016). Causes and consequences of oxidative stress in spermatozoa. Reproduction, Fertility, and Development, 28(2), 1-10. https://doi. org/10.1071/RD15325

Aitken, R., Harkiss, D., \& Buckingham, D. (1993). Relationship between iron-catalysed lipid peroxidation potential and human sperm function. Journal of Reproduction and Fertility, 98(1), 257-265. https://doi. org/10.1530/jrf.0.0980257

Aitken, R. J., \& Koppers, A. J. (2011). Apoptosis and DNA damage in human spermatozoa. Asian Journal of Andrology, 13(1), 36-42. https:// doi.org/10.1038/aja.2010.68
Alvarez, J. G., \& Storey, B. T. (1995). Differential incorporation of fatty acids into and peroxidative loss of fatty acids from phospholipids of human spermatozoa. Molecular Reproduction and Development, 42(3), 334-346. https://doi.org/10.1002/mrd.1080420311

Ayaz, A., Agarwal, A., Sharma, R., Arafa, M., Elbardisi, H., \& Cui, C. (2015). Impact of precise modulation of reactive oxygen species levels on spermatozoa proteins in infertile men. Clinical Proteomics, 12(1), 4. https://doi.org/10.1186/1559-0275-12-4

Baehner, R. L., Boxer, L. A., \& Davis, J. (1976). The biochemical basis of nitroblue tetrazolium reduction in normal human and chronic granulomatous disease polymorphonuclear leukocytes. Blood, 48(2), 309313. https://doi.org/10.1182/blood.V48.2.309.309

Baker, M. A., Weinberg, A., Hetherington, L., Villaverde, A.-I., Velkov, T., Baell, J., \& Gordon, C. P. (2015). Defining the mechanisms by which the reactive oxygen species by-product, 4-hydroxynonenal, affects human sperm cell function. Biology of Reproduction, 92(4), 101-110.

Bakos, H. W., Henshaw, R. C., Mitchell, M., \& Lane, M. (2011). Paternal body mass index is associated with decreased blastocyst development and reduced live birth rates following assisted reproductive technology. Fertility and Sterility, 95(5), 1700-1704. https://doi. org/10.1016/j.fertnstert.2010.11.044

Benjamin, D., Sharma, R. K., Moazzam, A., \& Agarwal, A. (2012). Methods for the detection of ROS in human sperm samples. Chapter 13. In Studies on men's health and fertility (pp 257-274). A. Agarwal, R. J. Aitken, \& J. G. Alvarez (Eds.), New York, NY: Springer Science + Business Media.

Bisht, S., \& Dada, R. (2017). Oxidative stress: Major executioner in disease pathology, role in sperm DNA damage and preventive strategies. Frontiers in Bioscience (Schol Ed), 9, 420-447. https://doi. org/10.2741/s495

Bisht, S., Faiq, M., Tolahunase, M., \& Dada, R. (2017). Oxidative stress and male infertility. Nature Reviews Urology, 14(8), 470-485. https:// doi.org/10.1038/nrurol.2017.69

Björndahl, L., Mortimer, D., Barratt, C. L., Castilla, J. A., Menkveld, R., Kvist, U., ... Haugen, T. B. (2010). A practical guide to basic laboratory andrology, New York: Cambridge University Press.

Borovic, S., Rabuzin, F., Waeg, G., \& Zarkovic, N. (2006). Enzymelinked immunosorbent assay for 4-hydroxynonenal-histidine conjugates. Free Radical Research, 40(8), 809-820. https://doi. org/10.1080/10715760600693422

Bourne, H., Archer, J., Edgar, D. H., \& Gordan Baker, H. W. (2009). Sperm preparation techniques. Chapter 5. In D. K. Gardner, A. Weismann, C. M. Howles, \& Z. Soham (Eds.), Textbook of assisted reproductive techniques: Laboratory and clinical perspectives (3rd ed., pp. 53-66). Boca Raton, FL: Informa Health Care, Taylor and Francis.

Brohi, R. D., \& Huo, L.-J. (2017). Posttranslational modifications in spermatozoa and effects on male fertility and sperm viability. OMICS: A Journal of Integrative Biology, 21(5), 245-256. https://doi. org/10.1089/omi.2016.0173

Cooper, T. G., Noonan, E., von Eckardstein, S., Auger, J., Baker, H. W. G., Behre, H. M., ... Vogelsong, K. M. (2010). World Health Organization reference values for human semen characteristics. Human Reproduction Update, 16(3), 231-245. https://doi.org/10.1093/ humupd/dmp048

Dalle-Donne, I., Rossi, R., Colombo, R., Giustarini, D., \& Milzani, A. (2006). Biomarkers of oxidative damage in human disease. Clinical Chemistry, 52(4), 601-623. https://doi.org/10.1373/clinc hem. 2005.061408

Darbandi, M., Darbandi, S., Agarwal, A., Sengupta, P., Durairajanayagam, D., Henkel, R., \& Sadeghi, M. R. (2018). Reactive oxygen species and male reproductive hormones. Reproductive Biology and Endocrinology, 16(1), 87. https://doi.org/10.1186/s12958-018-0406-2

De Iuliis, G. N., Thomson, L. K., Mitchell, L. A., Finnie, J. M., Koppers, A. J., Hedges, A., ... Aitken, R. J. (2009). DNA damage in human 
spermatozoa is highly correlated with the efficiency of chromatin remodeling and the formation of 8-hydroxy-2'-deoxyguanosine, a marker of oxidative stress. Biology of Reproduction, 81(3), 517-524.

De Iuliis, G. N., Wingate, J. K., Koppers, A. J., McLaughlin, E. A., \& Aitken, R. J. (2006). Definitive evidence for the nonmitochondrial production of superoxide anion by human spermatozoa. Journal of Clinical Endocrinology and Metabolism, 91(5), 1968-1975. https://doi. org/10.1210/jc.2005-2711

de la Calle, J. F. V., Muller, A., Walschaerts, M., Clavere, J. L., Jimenez, C., Wittemer, C., \& Thonneau, P. (2008). Sperm deoxyribonucleic acid fragmentation as assessed by the sperm chromatin dispersion test in assisted reproductive technology programs: Results of a large prospective multicenter study. Fertility and Sterility, 90(5), 1792-1799. https://doi.org/10.1016/j.fertnstert.2007.09.021

De Lamirande, E., \& Gagnon, C. (1995). Impact of reactive oxygen species on spermatozoa: A balancing act between beneficial and detrimental effects. Human Reproduction, 10(1), 15-21. https://doi.org/10.1093/ humrep/10.suppl_1.15

de Lamirande, E., Jiang, H., Zini, A., Kodama, H., \& Gagnon, C. (1997). Reactive oxygen species and sperm physiology. Reviews of Reproduction, 2(1), 48-54. https://doi.org/10.1530/ror.0.0020048

Dikalov, S. I., \& Harrison, D. G. (2014). Methods for detection of mitochondrial and cellular reactive oxygen species. Antiox Redox Signal, 20(2), 372-382. https://doi.org/10.1089/ars.2012.4886

Dikalov, S. I., Polienko, Y. F., \& Kirilyuk, I. (2018). Electron paramagnetic resonance measurements of reactive oxygen species by cyclic hydroxylamine spin probes. Antioxidants \& Redox Signaling, 28(15), 1433-1443. https://doi.org/10.1089/ars.2017.7396

Du Plessis, S. S., Agarwal, A., Halabi, J., \& Tvrda, E. (2015). Contemporary evidence on the physiological role of reactive oxygen species in human sperm function. Journal of Assisted Reproduction and Genetics 32(4), 509-520. https://doi.org/10.1007/s10815-014-0425-7

Durairajanayagam, D. (2018). Lifestyle causes of male infertility. Arab Journal of Urology, 16(1), 10-20. https://doi.org/10.1016/j. aju.2017.12.004

Dutta, S., Henkel, R., Sengupta, P., \& Agarwal, A. (2020). Physiological role of ROS in sperm function. In S. J. Parekattil, S. C. Esteves, \& A. Agarwal (Eds.), Male infertility: Contemporary clinical approaches, andrology, art and antioxidants (2nd ed., pp. 337-345). Switzerland: Springer Nature, Switzerland AG.

Endtz, A. (1974). A rapid staining method for differentiating granulocytes from "germinal cells" in Papanicolaou-stained semen. Acta Cytologica, 18(1), 2-7.

Engvall, E., Jonsson, K., \& Perlmann, P. (1971). Enzyme-linked immunosorbent assay. II. Quantitative assay of protein antigen, immunoglobulin G, by means of enzyme-labelled antigen and antibody-coated tubes. Biochimica et Biophysica Acta, 251(3), 427-434.

Esfandiari, N., Sharma, R. K., Saleh, R. A., Thomas Jr., A. J., \& Agarwal, A. (2003). Utility of the nitroblue tetrazolium reduction test for assessment of reactive oxygen species production by seminal leukocytes and spermatozoa. Journal of Andrology, 24(6), 862-870. https://doi. org/10.1002/j.1939-4640.2003.tb03137.x

Esteves, S. C., Gosálvez, J., LópezFernández, C., Núñez-Calonge, R., Caballero, P., Agarwal, A., \& Fernández, J. L. (2015). Diagnostic accuracy of sperm DNA degradation index (DDSi) as a potential noninvasive biomarker to identify men with varicocele-associated infertility. International Urology and Nephrology, 47(9), 1471-1477. https://doi. org/10.1007/s11255-015-1053-6

Evenson, D. P. (2016). The Sperm Chromatin Structure Assay (SCSA $®$ ) and other sperm DNA fragmentation tests for evaluation of sperm nuclear DNA integrity as related to fertility. Animal Reproduction Science, 169, 56-75. https://doi.org/10.1016/j.anireprosci.2016.01.017

Evenson, D. P., Larson, K. L., \& Jost, L. K. (2002). Sperm chromatin structure assay: Its clinical use for detecting sperm DNA fragmentation in male infertility and comparisons with other techniques. Journal of
Andrology, 23(1), 25-43. https://doi.org/10.1002/j.1939-4640.2002. tb02599.x

Evenson, D., \& Wixon, R. (2006). Meta-analysis of sperm DNA fragmentation using the sperm chromatin structure assay. Reproductive BioMedicine Online, 12(4), 466-472. https://doi.org/10.1016/S1472 $-6483(10) 62000-7$

Feijó, C. M., \& Esteves, S. C. (2014). Diagnostic accuracy of sperm chromatin dispersion test to evaluate sperm deoxyribonucleic acid damage in men with unexplained infertility. Fertility and Sterility, 101(1), 58-63.e3. https://doi.org/10.1016/j.fertnstert.2013.09.002

Fernández, J. L., Muriel, L., Goyanes, V., Segrelles, E., Gosálvez, J., Enciso, M., ... De Jonge, C. (2005). Halosperm ${ }^{\circledR}$ is an easy, available, and cost-effective alternative for determining sperm DNA fragmentation. Fertility and Sterility, 84(4), 832-842. https://doi.org/10.1016/j. fertnstert.2005.05.013

Fernández, J. L., Muriel, L., Rivero, M. T., Goyanes, V., Vazquez, R., \& Alvarez, J. G. (2003). The sperm chromatin dispersion test: A simple method for the determination of sperm DNA fragmentation. Journal of Andrology, 24(1), 59-66.

Ford, W. (2004). Regulation of sperm function by reactive oxygen species. Human Reproduction Update, 10(5), 387-399. https://doi. org/10.1093/humupd/dmh034

Fujii, J., \& Imai, H. (2014). Redox reactions in mammalian spermatogenesis and the potential targets of reactive oxygen species under oxidative stress. Spermatogenesis, 4(2), e979108. https://doi. org/10.4161/21565562.2014.979108

Garolla, A., Cosci, I., Bertoldo, A., Sartini, B., Boudjema, E., \& Foresta, C. (2015). DNA double strand breaks in human spermatozoa can be predictive for assisted reproductive outcome. Reproductive BioMedicine Online, 31(1), 100-107. https://doi.org/10.1016/j.rbmo.2015.03.009

Gomez, E., Buckingham, D. W., Brindle, J., Lanzafame, F., Irvine, D. S., \& Aitken, R. J. (1996). Development of an image analysis system to monitor the retention of residual cytoplasm by human spermatozoa: Correlation with biochemical markers of the cytoplasmic space, oxidative stress, and sperm function. Journal of Andrology, 17(3), 276-287.

Gosalvez, J., Tvrda, E., \& Agarwal, A. (2017). Free radical and superoxide reactivity detection in semen quality assessment: Past, present, and future. Journal of Assisted Reproduction and Genetics, 34(6), 697-707. https://doi.org/10.1007/s10815-017-0912-8

Gupta, S., Sharma, R., \& Agarwal, A. (2017). Inter-and intra-laboratory standardization of TUNEL assay for assessment of sperm DNA fragmentation. Current Protocols in Toxicology, 74(1), 11-16. https://doi. org/10.1002/cptx.37

Halliwell, B., \& Chirico, S. (1993). Lipid peroxidation: Its mechanism, measurement, and significance. American Journal of Clinical Nutrition, 57(5), 715S-724S. https://doi.org/10.1093/ajcn/57.5.715S

Henkel, R. R. (2011). Leukocytes and oxidative stress: Dilemma for sperm function and male fertility. Asian Journal of Andrology, 13(1), 43-52. https://doi.org/10.1038/aja.2010.76

Henkel, R., Kierspel, E., Hajimohammad, M., Stalf, T., Hoogendijk, C., Mehnert, C., ... Kruger, T. F. (2003). DNA fragmentation of spermatozoa and assisted reproduction technology. Reproductive BioMedicine Online, 7(4), 477-484. https://doi.org/10.1016/S1472 $-6483(10) 61893-7$

Henkel, R., Kierspel, E., Stalf, T., Mehnert, C., Menkveld, R., Tinneberg, H.-R., ... Kruger, T. F. (2005). Effect of reactive oxygen species produced by spermatozoa and leukocytes on sperm functions in non-leukocytospermic patients. Fertility and Sterility, 83(3), 635-642. https://doi.org/10.1016/j.fertnstert.2004.11.022

Henkel, R., Sandhu, I. S., Agarwal, A. (2019). The excessive use of antioxidant therapy: A possible cause of male infertility? Andrologia, 51(1), e13162. https://doi.org/10.1111/and.13162

Henkel, R. R., \& Schill, W.-B. (2003). Sperm preparation for ART. Reproductive Biology and Endocrinology, 1(1), 108. 
Hsieh, Y.-Y., Chang, C.-C., \& Lin, C.-S. (2006). Seminal malondialdehyde concentration but not glutathione peroxidase activity is negatively correlated with seminal concentration and motility. International Journal of Biological Sciences, 2(1), 23-29.

Khosrowbeygi, A., \& Zarghami, N. (2007). Fatty acid composition of human spermatozoa and seminal plasma levels of oxidative stress biomarkers in subfertile males. Prostaglandins Leukotrienes and Essential Fatty Acids, 77(2), 117-121. https://doi.org/10.1016/j.plefa.2007.08.003

Kodama, H., Yamaguchi, R., Fukuda, J., Kasai, H., \& Tanaka, T. (1997). Increased oxidative deoxyribonucleic acid damage in the spermatozoa of infertile male patients. Fertility and Sterility, 68(3), 519-524. https://doi.org/10.1016/S0015-0282(97)00236-7

Kohno, M. (2010). Applications of electron spin resonance spectrometry for reactive oxygen species and reactive nitrogen species research. Journal of Clinical Biochemistry and Nutrition, 47(1), 1-11. https://doi. org/10.3164/jcbn.10-13R

Kopáni, M., Celec, P., Danišovič, L., Michalka, P., \& Biró, C. (2006). Oxidative stress and electron spin resonance. Clinica Chimica Acta, 364(1-2), 61-66. https://doi.org/10.1016/j.cca.2005.05.016

Koppers, A. J., De luliis, G. N., Finnie, J. M., McLaughlin, E. A., \& Aitken, R. J. (2008). Significance of mitochondrial reactive oxygen species in the generation of oxidative stress in spermatozoa. Journal of Clinical Endocrinology and Metabolism, 93(8), 3199-3207. https://doi. org/10.1210/jc.2007-2616

Li, K., Shang, X., \& Chen, Y. (2004). High-performance liquid chromatographic detection of lipid peroxidation in human seminal plasma and its application to male infertility. Clinica Chimica Acta, 346(2), 199203. https://doi.org/10.1016/j.cccn.2004.03.013

Mack, S., Everingham, J., \& Zaneveld, L. (1986). Isolation and partial characterization of the plasma membrane from human spermatozoa. Journal of Experimental Zoology, 240(1), 127-136. https://doi. org/10.1002/jez.1402400116

Mahfouz, R. Z., du Plessis, S. S., Aziz, N., Sharma, R., Sabanegh, E., \& Agarwal, A. (2010). Sperm viability, apoptosis, and intracellular reactive oxygen species levels in human spermatozoa before and after induction of oxidative stress. Fertility and Sterility, 93(3), 814-821. https://doi.org/10.1016/j.fertnstert.2008.10.068

Mahfouz, R., Sharma, R., Lackner, L., Aziz, N., \& Agarwal, A. (2009a). Evaluation of chemiluminescence and flow cytometry as tools in assessing production of hydrogen peroxide and superoxide anion in human spermatozoa. Fertility and Sterility, 92(2), 819-827. https://doi. org/10.1016/j.fertnstert.2008.05.087

Mahfouz, R. Z., Sharma, R. K., Said, T. M., Erenpreiss, J., \& Agarwal, A. (2009b). Association of sperm apoptosis and DNA ploidy with sperm chromatin quality in human spermatozoa. Fertility and Sterility, 91(4), 1110-1118. https://doi.org/10.1016/j.fertnstert.2008.01.047

Majzoub, A., Agarwal, A., Cho, C.-L., \& Esteves, S. C. (2017). Sperm DNA fragmentation testing: A cross sectional survey on current practices of fertility specialists. Translational Andrology and Urology, 6(Suppl 4), S710-S719. https://doi.org/10.21037/tau.2017.06.21

Makker, K., Agarwal, A., \& Sharma, R. (2009). Oxidative stress \& male infertility. Indian Journal of Medical Research, 129(4), 357-367.

Mathews, S. T., Plaisance, E. P., \& Kim, T. (2009). Imaging systems for westerns: Chemiluminescence vs. infrared detection. Protein Blotting and Detection, Methods Molecular Biology, 536, 499-513.

Menezo, Y. J., Silvestris, E., Dale, B., \& Elder, K. (2016). Oxidative stress and alterations in DNA methylation: Two sides of the same coin in reproduction. Reproductive BioMedicine Online, 33(6), 668-683. https://doi.org/10.1016/j.rbmo.2016.09.006

Moazamian, R., Polhemus, A., Connaughton, H., Fraser, B., Whiting, S., Gharagozloo, P., \& Aitken, R. J. (2015). Oxidative stress and human spermatozoa: Diagnostic and functional significance of aldehydes generated as a result of lipid peroxidation. Molecular Human Reproduction, 21(6), 502-515. https://doi.org/10.1093/molehr/ gav014
Mortimer, D. (1994). David mortimer sperm washing. Practical laboratory andrology. New York, NY: Oxford University Press.

Mupfiga, C., Fisher, D., Kruger, T., \& Henkel, R. (2013). The relationship between seminal leukocytes, oxidative status in the ejaculate, and apoptotic markers in human spermatozoa. Systems Biology in Reproductive Medicine, 59(6), 304-311. https://doi. org/10.3109/19396368.2013.821540

Muratori, M., Tamburrino, L., Marchiani, S., Cambi, M., Olivito, B., Azzari, C., ... Baldi, E. (2015). Investigation on the origin of sperm DNA fragmentation: Role of apoptosis, immaturity and oxidative stress. Molecular Medicine, 21(1), 109-122. https://doi.org/10.2119/ molmed.2014.00158

Muriel, L., Garrido, N., Fernández, J. L., Remohí, J., Pellicer, A., de los Santos, M. J., \& Meseguer, M. (2006). Value of the sperm deoxyribonucleic acid fragmentation level, as measured by the sperm chromatin dispersion test, in the outcome of in vitro fertilization and intracytoplasmic sperm injection. Fertility and Sterility, 85(2), 371-383. https://doi.org/10.1016/j.fertnstert.2005.07.1327

Myhre, O., Andersen, J. M., Aarnes, H., \& Fonnum, F. (2003). Evaluation of the probes $2^{\prime}, 7^{\prime}$-dichlorofluorescin diacetate, luminol, and lucigenin as indicators of reactive species formation. Biochemical Pharmacology, 65(10), 1575-1582. https://doi.org/10.1016/S0006 -2952(03)00083-2

Nakajima, Y., Nakashima, T., Inaba, K., Sumida, Y., Yoh, T., Ishikawa, H., ... Senmaru, H. (2002). Effects of nitric oxide on the redox status of liver microsomes-electron spin resonance monitoring using nitroxide probes. Hepatology Research, 24(1), 72-79. https://doi.org/10.1016/ S1386-6346(02)00011-6

Nohl, H., Staniek, K., Sobhian, B., Bahrami, S., Redl, H., \& Kozlov, A. V. (2000). Mitochondria recycle nitrite back to the bioregulator nitric monoxide. Acta Biochimica Polonica, 47(4), 913-921. https://doi. org/10.18388/abp.2000_3946

O'Flaherty, C., \& Matsushita-Fournier, D. (2017). Reactive oxygen species and protein modifications in spermatozoa. Biology of Reproduction, 97(4), 577-585. https://doi.org/10.1093/biolre/iox104

Palmer, N. O., Bakos, H. W., Fullston, T., \& Lane, M. (2012). Impact of obesity on male fertility, sperm function and molecular composition. Spermatogenesis, 2(4), 253-263. https://doi.org/10.4161/ spmg.21362

Pasqualotto, F. F., Sharma, R. K., Pasqualotto, E. B., \& Agarwal, A. (2008). Poor semen quality and ROS-TAC scores in patients with idiopathic infertility. Urologia Internationalis, 81(3), 263-270. https://doi. org/10.1159/000151401

Plante, M., de Lamirande, E., \& Gagnon, C. (1994). Reactive oxygen species released by activated neutrophils, but not by deficient spermatozoa, are sufficient to affect normal sperm motility. Fertility and Sterility, 62(2), 387-393. https://doi.org/10.1016/S0015-0282(16)56895-2

Poulos, A., Darin-Bennett, A., \& White, I. (1973). The phospholipid-bound fatty acids and aldehydes of mammalian spermatozoa. Comparative Biochemistry and Physiology Part B: Comparative Biochemistry, 46(3), 541-549. https://doi.org/10.1016/0305-0491(73)90094-1

Radi, R. (2004). Nitric oxide, oxidants, and protein tyrosine nitration. Proceedings of the National Academy of Sciences, 101(12), 4003-4008. https://doi.org/10.1073/pnas.0307446101.

Rael, L. T., Bar-Or, R., Kelly, M. T., Carrick, M. M., \& Bar-Or, D. (2015). Assessment of oxidative stress in patients with an isolated traumatic brain injury using disposable electrochemical test strips. Electroanalysis, 27(11), 2567-2573. https://doi.org/10.1002/ elan.201500178

Ren, S.-S., Sun, G.-H., Ku, C.-H., Chen, D.-C., \& Wu, G.-J. (2004). Comparison of four methods for sperm preparation for IUI. Archives of Andrology, 50(3), 139-143. https://doi.org/10.1080/0148501049 0425566

Ribas-Maynou, J., García-Peiró, A., Fernández-Encinas, A., Abad, C., Amengual, M., Prada, E., ... Benet, J. (2013). Comprehensive analysis 
of sperm DNA fragmentation by five different assays: TUNEL assay, SCSA, SCD test and alkaline and neutral Comet assay. Andrology, 1(5), 715-722. https://doi.org/10.1111/j.2047-2927.2013.00111.x

Rothe, G., \& Valet, G. (1990). Flow cytometric analysis of respiratory burst activity in phagocytes with hydroethidine and 2', 7'-dichlorofluorescin. Journal of Leukocyte Biology, 47(5), 440-448. https://doi. org/10.1002/jlb.47.5.440

Roychoudhury, S., Sharma, R., Sikka, S., \& Agarwal, A. (2016). Diagnostic application of total antioxidant capacity in seminal plasma to assess oxidative stress in male factor infertility. Journal of Assisted Reproduction and Genetics, 33(5), 627-635. https://doi.org/10.1007/ s10815-016-0677-5

Sakkas, D., \& Alvarez, J. G. (2010). Sperm DNA fragmentation: Mechanisms of origin, impact on reproductive outcome, and analysis. Fertility and Sterility, 93(4), 1027-1036. https://doi.org/10.1016/j. fertnstert.2009.10.046

Sakkas, D., Mariethoz, E., Manicardi, G., Bizzaro, B., Bianchi, P. G., \& Bianchi, U. (1999). Origin of DNA damage in ejaculated human spermatozoa. Reviews of Reproduction, 4(1), 31-37. https://doi. org/10.1530/ror.0.0040031

Samanta, L., Agarwal, A., Swain, N., Sharma, R., Gopalan, B., Esteves, S. C., ... Sabanegh, E. (2018). Proteomic signatures of sperm mitochondria in varicocele: Clinical use as biomarkers of varicocele associated infertility. Journal of Urology, 200(2), 414-422. https://doi. org/10.1016/j.juro.2018.03.009

Samanta, L., Swain, N., Ayaz, A., Venugopal, V., \& Agarwal, A. (2016). Post-Translational Modifications in sperm Proteome: The chemistry of proteome diversifications in the pathophysiology of male factor infertility. Biochimica Et Biophysica Acta (BBA) - General Subjects, 1860(7), 1450-1465. https://doi.org/10.1016/j.bbagen.2016.04.001

Shang, X.-J., Li, K., Ye, Z.-Q., Chen, Y.-G., Yu, X., \& Huang, Y.-F. (2004). Analysis of lipid peroxidative levels in seminal plasma of infertile men by high-performance liquid chromatography. Archives of Andrology, 50(6), 411-416. https://doi.org/10.1080/01485010490484138

Shapiro, H. M. (1972). Redox balance in the body: An approach to quantitation. Current Research Review, 13(3), 138-152. https://doi. org/10.1016/0022-4804(72)90057-1

Sharma, R., \& Agarwal, A. (2020). Oxidative stress measurement in semen and seminal plasma. In S. J. Parekattil, S. C. Esteves, \& A. Agarwal (Eds.), Male infertility: Contemporary clinical approaches, andrology, ART and antioxidants (2nd ed., pp. 69-97) Springer.

Sharma, R., Agarwal, A., Mohanty, G., Hamada, A. J., Gopalan, B., Willard, B., ... Du Plessis, S. (2013). Proteomic analysis of human spermatozoa proteins with oxidative stress. Reproductive Biology and Endocrinology, 11(1), 48. https://doi.org/10.1186/1477-7827-11-48

Sharma, R., Ahmad, G., Esteves, S. C., \& Agarwal, A. (2016). Terminal deoxynucleotidyl transferase dUTP nick end labeling (TUNEL) assay using bench top flow cytometer for evaluation of sperm DNA fragmentation in fertility laboratories: Protocol, reference values, and quality control. Journal of Assisted Reproduction and Genetics, 33(2), 291-300. https://doi.org/10.1007/s10815-015-0635-7

Sharma, R. K., Pasqualotto, F. F., Nelson, D. R., \& Agarwal, A. (2001). Relationship between seminal white blood cell counts and oxidative stress in men treated at an infertility clinic. Journal of Andrology, 22(4), 575-583.

Sharma, R. K., Pasqualotto, F. F., Nelson, D. R., Thomas Jr., A. J., \& Agarwal, A. (1999). The reactive oxygen species-total antioxidant capacity score is a new measure of oxidative stress to predict male infertility. Human Reproduction, 14(11), 2801-2807. https://doi. org/10.1093/humrep/14.11.2801

Sharma, R. K., Sabanegh, E., Mahfouz, R., Gupta, G., Thiyagarajan, A., \& Agarwal, A. (2010). TUNEL as a test for sperm DNA damage in the evaluation of male infertility. Urology, 76(6), 1380-1386. https://doi. org/10.1016/j.urology.2010.04.036
Shekarriz, M., Sharma, R., Thomas, A., \& Agarwal, A. (1995). Positive myeloperoxidase staining (Endtz test) as an indicator of excessive reactive oxygen species formation in semen. Journal of Assisted Reproduction and Genetics, 12(2), 70-74. https://doi.org/10.1007/ BF02211372

Sigman, M., Lipshultz, L., \& Howards, S. (2009). Office evaluation of the subfertile male. Chapter 10. In L. Lipshultz, S. S. Niederberger, \& C. Howards (Eds.), Infertility in the male (4th ed., pp. 153-176). Cambridge: Cambridge University Press.

Signorini, C., Comporti, M., \& Giorgi, G. (2003). Ion trap tandem mass spectrometric determination of F2-isoprostanes. Journal of Mass Spectrometry, 38(10), 1067-1074. https://doi.org/10.1002/jms.520

Signorini, C., Perrone, S., Sgherri, C., Ciccoli, L., Buonocore, G., Leoncini, S., ... Comporti, M. (2008). Plasma esterified F 2-isoprostanes and oxidative stress in newborns: Role of nonprotein-bound iron. Pediatric Research, 63(3), 287-291. https://doi.org/10.1203/PDR.0b013 e318163a1fd

Singh, N. P., Danner, D. B., Tice, R. R., McCoy, M. T., Collins, G. D., \& Schneider, E. L. (1989). Abundant alkali-sensitive sites in DNA of human and mouse sperm. Experimental Cell Research, 184(2), 461470. https://doi.org/10.1016/0014-4827(89)90344-3

Singh, N. P., McCoy, M. T., Tice, R. R., \& Schneider, E. L. (1988). A simple technique for quantitation of low levels of DNA damage in individual cells. Experimental Cell Research, 175(1), 184-191. https://doi. org/10.1016/0014-4827(88)90265-0

Spickett, C. M. (2013). The lipid peroxidation product 4-hydroxy-2-nonenal: Advances in chemistry and analysis. Redox Biology, 1(1), 145152. https://doi.org/10.1016/j.redox.2013.01.007

Tavilani, H., Doosti, M., \& Saeidi, H. (2005). Malondialdehyde levels in sperm and seminal plasma of asthenozoospermic and its relationship with semen parameters. Clinica Chimica Acta, 356(1-2), 199-203. https://doi.org/10.1016/j.cccn.2005.01.017

Tavilani, H., Goodarzi, M. T., Doosti, M., Vaisi-Raygani, A., Hassanzadeh, T., Salimi, S., \& Joshaghani, H. R. (2008). Relationship between seminal antioxidant enzymes and the phospholipid and fatty acid composition of spermatozoa. Reproductive BioMedicine Online, 16(5), 649-656. https://doi.org/10.1016/S1472-6483(10)60478-6

Tremellen, K. (2008). Oxidative stress and male infertility - A clinical perspective. Human Reproduction Update, 14(3), 243-258. https:// doi.org/10.1093/humupd/dmn004

Tunc, O., Thompson, J., \& Tremellen, K. (2010). Development of the NBT assay as a marker of sperm oxidative stress. International Journal of Andrology, 33(1), 13-21. https://doi. org/10.1111/j.1365-2605.2008.00941.x

Tunc, O., \& Tremellen, K. (2009). Oxidative DNA damage impairs global sperm DNA methylation in infertile men. Journal of Assisted Reproduction and Genetics, 26(9-10), 537-544.

Vezin, H., Lamour, E., Routier, S., Villain, F., Bailly, C., Bernier, J.-L., \& Catteau, J. P. (2002). Free radical production by hydroxy-salen manganese complexes studied by ESR and XANES. Journal of Inorganic Biochemistry, 92(3-4), 177-182. https://doi.org/10.1016/S0162 -0134(02)00558-5

Vorilhon, S., Brugnon, F., Kocer, A., Dollet, S., Bourgne, C., Berger, M., ... Pons-Rejraji, H. (2018). Accuracy of human sperm DNA oxidation quantification and threshold determination using an 8-OHdG immuno-detection assay. Human Reproduction, 33(4), 553-562. https:// doi.org/10.1093/humrep/dey038

Wagner, H., Cheng, J. W., \& Ko, E. Y. (2018). Role of reactive oxygen species in male infertility: An updated review of literature. Arab Journal of Urology, 16(1), 35-43. https://doi.org/10.1016/j.aju.2017.11.001

Wahab, Y. A. W., Isa, M. K. L. M., \& Ramli, R. (2016). Spermatogonial stem cells protein identification in in vitro culture from non-obstructive azoospermia patient. Malaysian Journal of Medical Sciences, 23(3), 40-48. 
Wahab, Y. A. W., Yazmie, A., Isa, M., \& Lokman, M. (2015). The future of Azoospermic Patients: In vitro spermatogenesis. Andrology, 4(2), 1000143.

World Health Organization. (2010). WHO laboratory manual for the examination and processing of human semen (5th ed.). Geneva, Switzerland.

Wright, C., Milne, S., \& Leeson, H. (2014). Sperm DNA damage caused by oxidative stress: Modifiable clinical, lifestyle and nutritional factors in male infertility. Reproductive BioMedicine Online, 28(6), 684-703. https://doi.org/10.1016/j.rbmo.2014.02.004

Zarkovic, N. (2003). 4-Hydroxynonenal as a bioactive marker of pathophysiological processes. Molecular Aspects of Medicine, 24(4-5), 281291. https://doi.org/10.1016/S0098-2997(03)00023-2

Zhou, T., Xia, X., Liu, J., Wang, G., Guo, Y., Guo, X., ... Sha, J. (2015). Beyond single modification: Reanalysis of the acetylproteome of human sperm reveals widespread multiple modifications. Journal of Proteomics, 126, 296-302. https://doi.org/10.1016/j. jprot.2015.05.022
Zielonka, J., Vasquez-Vivar, J., \& Kalyanaraman, B. (2008). Detection of 2-hydroxyethidium in cellular systems: A unique marker product of superoxide and hydroethidine. Nature Protocols, 3(1), 8-21. https:// doi.org/10.1038/nprot.2007.473

Zini, A., Boman, J. M., Belzile, E., \& Ciampi, A. (2008). Sperm DNA damage is associated with an increased risk of pregnancy loss after IVF and ICSI: Systematic review and meta-analysis. Human Reproduction, 23(12), 2663-2668. https://doi.org/10.1093/humrep/den321

How to cite this article: Robert KA, Sharma R, Henkel R, Agarwal A. An update on the techniques used to measure oxidative stress in seminal plasma. Andrologia.

2021;53:e13726. https://doi.org/10.1111/and.13726 